University of Nebraska - Lincoln

DigitalCommons@University of Nebraska - Lincoln

\title{
Survey of the Golden-Cheeked Warbler on Fort Hood in Support of NEPA Requirements
}

\author{
Bruce MacAllister \\ U.S. Army Engineer Research and Development Center \\ Tim Hayden \\ U.S. Army Engineer Research and Development Center \\ Michael Baranski \\ Jones Technology Inc. \\ Rebecca Peak \\ The Nature Conservancy
}

Follow this and additional works at: https://digitalcommons.unl.edu/usarmyceomaha

Part of the Civil and Environmental Engineering Commons

MacAllister, Bruce; Hayden, Tim; Baranski, Michael; and Peak, Rebecca, "Survey of the Golden-Cheeked Warbler on Fort Hood in Support of NEPA Requirements" (2007). US Army Corps of Engineers. 141. https://digitalcommons.unl.edu/usarmyceomaha/141

This Article is brought to you for free and open access by the U.S. Department of Defense at DigitalCommons@University of Nebraska - Lincoln. It has been accepted for inclusion in US Army Corps of Engineers by an authorized administrator of DigitalCommons@University of Nebraska - Lincoln. 


\section{Survey of the Golden-Cheeked Warbler on Fort Hood in Support of NEPA Requirements}

\section{US Army Corps of Engineers $s_{\circledast}$} Engineer Research and Development Center

Bruce MacAllister, Michael Baranski, Tim Hayden, and

Rebecca Peak

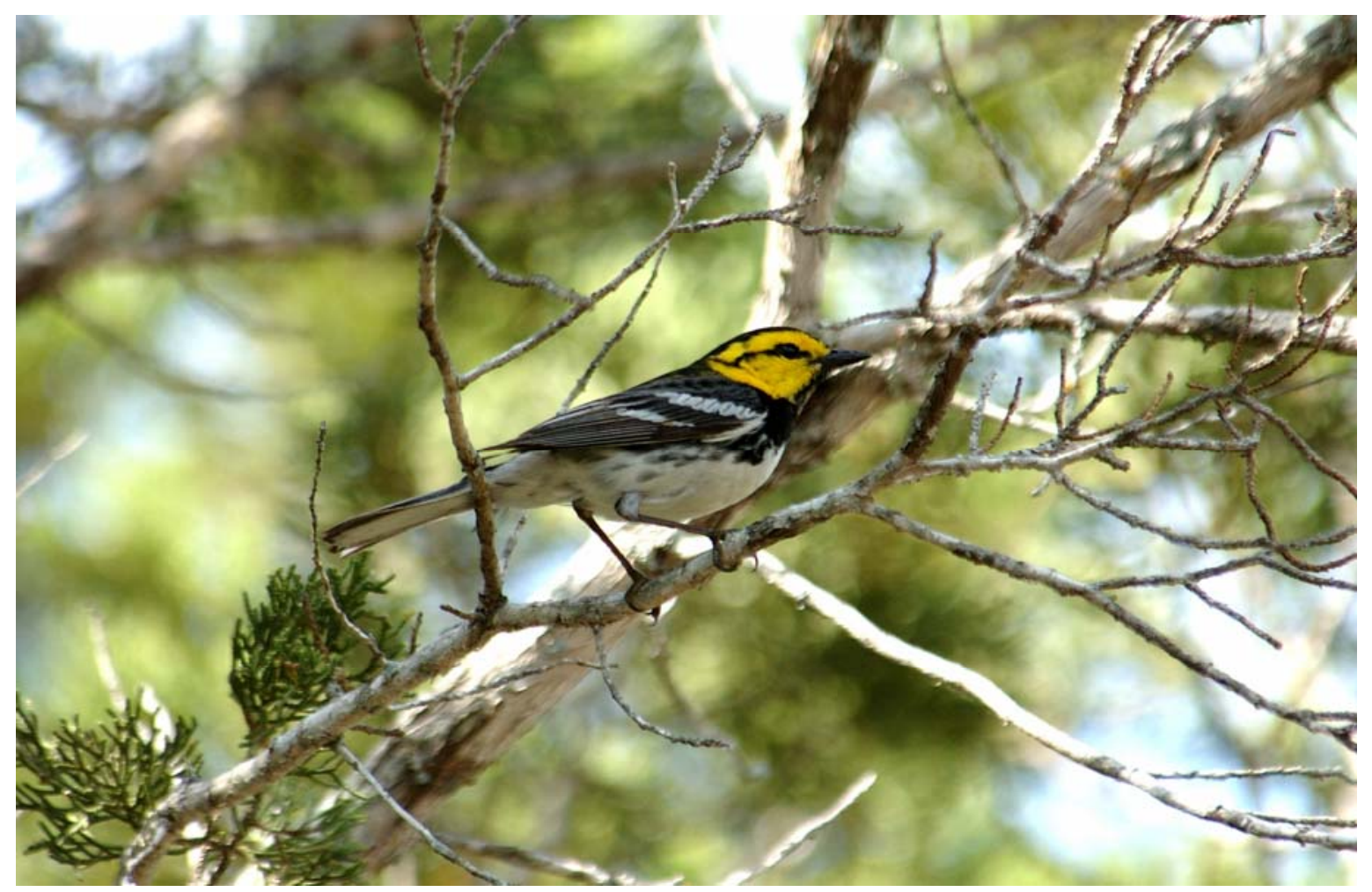




\title{
Survey of the Golden-Cheeked Warbler on Fort Hood in Support of NEPA Requirements
}

\author{
Bruce MacAllister and Tim Hayden \\ Construction Engineering Research Laboratory \\ U.S. Army Engineer Research and Development Center \\ 2902 Newmark Dr. \\ Champaign, IL 61822-1076 \\ Michael Baranski \\ Jones Technology Inc. \\ 4601 Presidents Drive, Suite 145 \\ Lanham, MD 20706 \\ Rebecca Peak \\ The Nature Conservancy \\ P.O. Box 5190 \\ Fort Hood, TX 76544
}

Final report

Approved for public release; distribution is unlimited.

Cover photograph by Michael Baranski

Prepared for U.S. Army Environmental Center

5179 Hoadley Road

Aberdeen Proving Ground, MD 21010-5401

Under Work Unit MIPR5L48R00091 


\begin{abstract}
This research on the golden-cheeked warbler (GCW) was conducted on Fort Hood, Texas, during April and June 2006. Subject matter experts on Fort Hood were consulted and helped determine which areas of the installation contained suitable GCW habitat but were not already included in The Nature Conservancy's intensive study program. Researchers then surveyed one of these areas, documenting the presence of GCW. This research was conducted to determine if data collected in the intensive study area has been successfully extrapolated to other areas of habitat on the installation.
\end{abstract}

The collected data showed that the territory density was lower than those found on TNC's intensive study areas, but pairing success was very similar to the TNC data, and the number of territorial males producing $\geq 1$ fledgling was considerably higher than TNC's estimates.

This study supports the possibility of extrapolating TNC's data to areas on Fort Hood that have not been intensively sampled. However, the small scope of this project and relatively low sample size make it necessary to preface the results with one caveat: additional years of data collection on this study site would equate to a higher measure of confidence in the results. 


\section{Executive Summary}

This research on the golden-cheeked warbler (GCW) was conducted on Fort Hood, Texas, during April and June 2006. Subject matter experts on Fort Hood were consulted and helped determine which areas of the installation contained suitable GCW habitat but were not already included in The Nature Conservancy's (TNC's) intensive study program. Researchers then surveyed one of these areas, documenting the presence of GCW, the numbers of birds seen or heard, and the demographics of the species within this new study area. This research was conducted to determine if data collected in the intensive study area has been successfully extrapolated to other areas of habitat on the installation.

The collected data showed that the territory density was lower than those found on TNC's intensive study areas, which may be the result of a lower number of territorial males present here due to habitat constraints, but pairing success was very similar to the data collected by TNC. However, the number of territorial males producing $\geq 1$ fledgling observed in this study was considerably higher than TNC's estimates. This may be due to inaccurate identification of unbanded males on the study area. When unbanded males live in adjacent territories, it is possible to observe the same male at varying times and locations and assume it was two or more different birds.

This study supports the possibility of extrapolating TNC's data to areas on Fort Hood that have not been intensively sampled. However, the small scope of this project and relatively low sample size make it necessary to preface the results with one caveat: additional years of data collection on this study site would equate to a higher measure of confidence in the results.

DISCLAIMER: The contents of this report are not to be used for advertising, publication, or promotional purposes. Citation of trade names does not constitute an official endorsement or approval of the use of such commercial products. All product names and trademarks cited are the property of their respective owners. The findings of this report are not to be construed as an official Department of the Army position unless so designated by other authorized documents. 


\section{Contents}

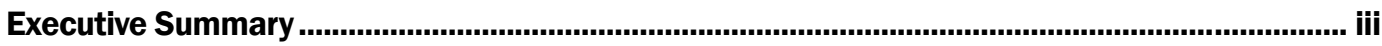

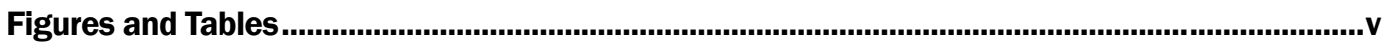

Preface .....................................................................................................................................................vi

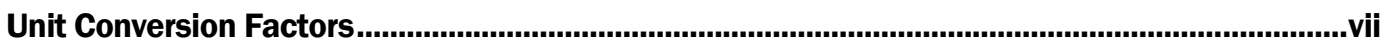

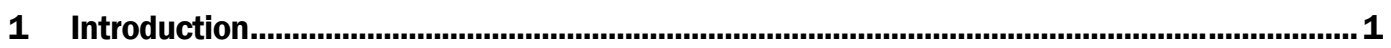

Background

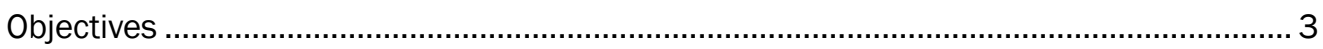

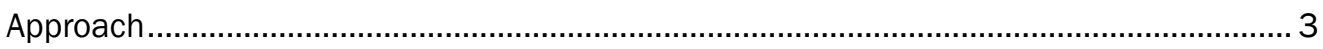

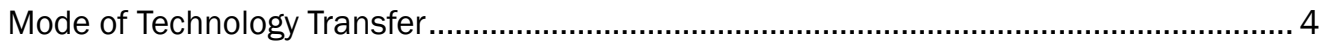

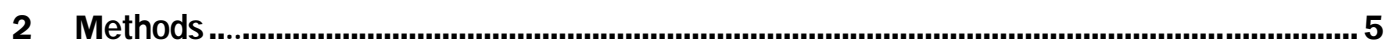

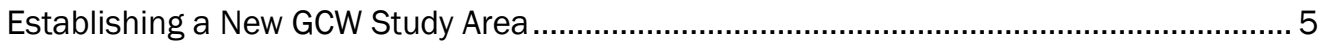

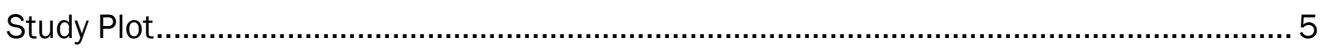

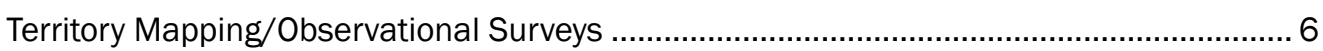

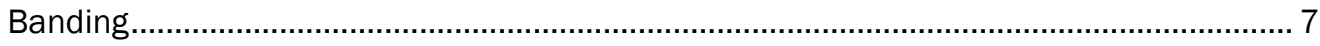

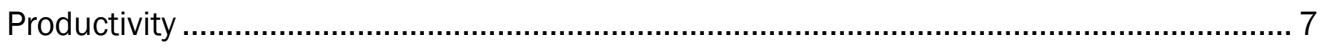

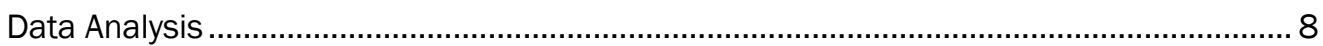

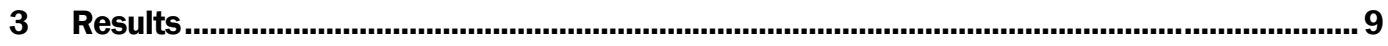

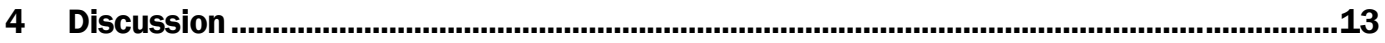

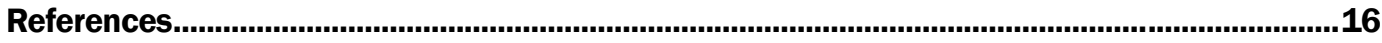

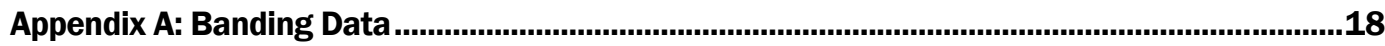

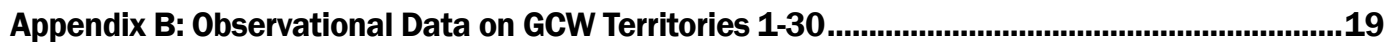

Appendix C: Nest Monitoring Data ..................................................................................

Report Documentation Page.............................................................................................. 41 


\section{Figures and Tables}

\section{Figures}

Figure 1. TNC Intensive Study Areas and ERDC-CERL Study Area on Fort Hood, Texas. .................... 6

Figure 2. Territory size/location and mated status of territorial males on Study Area....................... 10

Figure 3. Age structure of banded territorial males on study area.................................................. 11

Figure 4. Productivity of SY territorial males and ASY territorial males............................................... 11

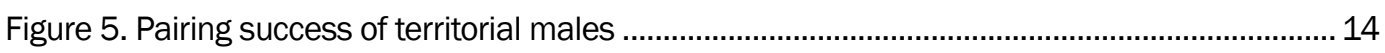

Figure 6. Number of territorial males producing $\geq 1$ fledgling....................................................... 14

\section{Tables}

Table 1. Overall territory density............................................................................................ 13 


\section{Preface}

This report is a deliverable product under military interdepartmental purchase request (MIPR) MIPR5L48Rooo91, "Environmental Survey for Fort Hood om Support of NEPA Requirements." This work was funded by the U.S. Army Environmental Center, SFIM-AEC-EQN. The Technical Monitor was Steve Sekscienski.

This report was prepared by Bruce MacAllister and Tim Hayden, Ecological Processes Branch (CN-N), Installations Division (CN), Construction Engineering Research Laboratory (CERL), U.S. Army Engineer Research and Development Center (ERDC), Michael Baranski, Jones Technology, and Rebecca Peak, The Nature Conservancy under the general supervision of Alan B. Anderson, Chief CN-N; Dr. John T. Bandy, Chief CN, and Dr. Ilker Adiguzel, Director, CERL. Technical supervision was provided by Dr. William D. Severinghaus, Technical Director.

COL Richard B. Jenkins was Commander and Executive Director of ERDC. Dr. James R. Houston was Director. 


\section{Unit Conversion Factors}

\begin{tabular}{|l|c|l|}
\hline Multiply & By & To Obtain \\
\hline acres & $4,046.873$ & square meters \\
\hline degrees Fahrenheit & $(\mathrm{F}-32) / 1.8$ & degrees Celsius \\
\hline feet & 0.3048 & meters \\
\hline hectares & $1.0 \mathrm{E}+04$ & square meters \\
\hline inches & 0.0254 & meters \\
\hline miles (U.S. statute) & $1,609.347$ & meters \\
\hline pounds (mass) & 0.45359237 & kilograms \\
\hline square feet & 0.09290304 & square meters \\
\hline square miles & $2.589998 \mathrm{E}+06$ & square meters \\
\hline
\end{tabular}




\section{Introduction}

\section{Background}

Fort Hood currently provides the infrastructure and training lands for the 1st Cavalry Division and the 4th Infantry Division (Mech), III Corps Headquarters and its combat aviation assets, combat support, and combat service support units. The 2005 Base Realignment and Closure (BRAC) Commission cited limitations in available maneuver training acreage as one of the reasons for recommending relocating Brigade Combat Teams and other support and combat element temporarily stationed at Fort Hood to Fort Carson, Colorado, and Fort Bliss, Texas. Although the net change from 2003 to 2011 in assigned personnel on Fort Hood as a result of BRAC initiatives will be negligible, the findings of the BRAC commission have resulted in increased evaluation of available military range lands on Fort Hood to support training activities. Historically, the eastern training ranges of Fort Hood north of Belton Lake (Land Groups 1 and 2) have received only limited use by mechanized units due to terrain and vegetation constraints. However, as training requirements increase use of all available training lands, these under-utilized ranges are receiving increased pressure to support additional training activities. These two land groups on Fort Hood also support the largest contiguous habitat area on the installation for the federally endangered golden-cheeked warbler. As a result of potential effects on populations and habitats of this endangered species, significant changes in the military use of Land Groups 1 and 2 could trigger compliance actions under both the National Environmental Policy Act (NEPA) and the Endangered Species Act (ESA). This effort will provide the installation baseline golden-cheeked warbler population and habitat use data that have not been previously collected in these land groups. These data can be used by installation land managers to assess effects of potential changes in mission activities in these land groups in compliance with NEPA and ESA requirements.

The golden-cheeked warbler (Dendroica chrysoparia) is a federally endangered migratory passerine with a breeding range endemic to the range of Ashe juniper (J uniperus ashei) on the Edward's Plateau of central Texas. The golden-cheeked warbler (GCW) is a medium sized warbler characterized by a distinctive black head, yellow face, and thin black eyeline. The GCW is entirely dependent upon the mature Ashe juniper forests 
of central Texas for nesting and foraging. The species builds its nests almost entirely from shredded juniper bark at a height of 4 to 5 meters above the ground, most commonly in Ashe juniper and occasionally in the hardwoods common to the region (e.g., live oak, Texas oak; Pulich 1976). Only mature Ashe juniper trees shred their bark, limiting the goldencheeked warbler to forests with a high proportion of juniper trees that are older than 40 to 50 years (Pulich 1976). Warblers, however, rarely exist in stands of pure juniper, as they also require the hardwoods that support the insect populations on which they forage. For a more detailed description of the golden-cheeked warbler and its habitat, see Pulich (1976).

The golden-cheeked warbler was listed as endangered in 1991 under the ESA of 1973, as amended due to degrading and increasingly fragmented habitat, which caused the decline in their population (Benson 1990). Pulich (1976) estimated the breeding population to be approximately 14,950 birds. In 1990, Wahl, Diamond, and Shaw estimated there were 4,822 to 16,016 breeding pairs but believed that their estimation of breeding pairs was "unrealistically" high. In 1995, the species was believed to breed in at least 24 central Texas counties, a reduction of 23percent from 1976 estimates (31 counties; Pulich 1976; U.S. Fish and Wildlife Service [USFWS] 1996). But since then, their numbers have been slowly increasing due to the efforts of natural resource managers responsible for overseeing the Army's endangered species program at Fort Hood, Texas, and organizations like The Nature Conservancy, which conducts extensive research efforts and conservation activities on the installation. It is currently estimated that approximately 21,422 ha $(52,935 \mathrm{ac})$ of suitable GCW habitat occur on Fort Hood (Hayden et al. 2001). Using GCW densities from areas intensively studied by TNC, the population on Fort Hood is currently estimated to range from 2,901 to 6,040 singing males. Observed density in 2003 on intensive study plots was $0.21 \mathrm{males} / \mathrm{ha}$, which when extrapolated to all available habitats produces an estimate of 4,514 territorial males (Peak 2003). For a more detailed habitat description of Fort Hood, see Tazik and Cornelius, 1993.

Fort Hood is located in Bell and Coryell counties in east central Texas. The Edwards Plateau and the breeding range of the GCW contain much of this installation. Vegetative cover on this installation varies with slope, aspect, moisture, and historic usage (cattle grazing, military activities, etc.). Vegetation here consists of grassland, open savannah, hardwood thickets, and dense Ashe juniper-oak stands. Fort Hood is one of the largest Army in- 
stallations, boasting the highest number of active duty armor personnel in the United States Armed Services. It covers a total of 339 square miles $(878 \mathrm{sq} \mathrm{km})$ and is the only post in the United States that supports two full armored divisions. As such, the training that occurs on Fort Hood is substantial. This training has, over the years since the GCW was listed, been impacted by known, unknown, or potential disturbances to this endangered species. Since populations of GCWs as well as other neotropical migrants are known to be less stable in areas with increased disturbance and/or habitat manipulation (Benson 1990, Engels 1995) restrictions have been placed on military training activities in and around GCW habitat on the installation.

\section{Objectives}

The objectives of this work were to determine and document (1) demographic parameters (return rates, dispersal distances, productivity, and mated status) affecting population status and (2) occurrence of the goldencheeked warbler in nonintensively studied habitat on Fort Hood, Texas, in support of NEPA and ESA requirements.

\section{Approach}

This research on the golden-cheeked warbler was conducted on Fort Hood, Texas, during April and June 2006. Subject matter experts on Fort Hood were consulted and helped determine which areas of the installation would contain suitable GCW habitat that was not already included in The Nature Conservancy's intensive study area. Researchers then surveyed these areas, documenting the presence of GCW and the number of birds seen or heard. Researchers also set about following the same protocol TNC currently uses for monitoring these birds in the intensive study areas established in 1991. This work included determining territory location and size, mated status, and productivity. The research work consisted of systematically surveying possible golden-cheeked warbler habitat, colorbanding adults, and monitoring the newly established study area to determine species productivity. These data were then compared to those gathered by TNC and used to extrapolate GCW population trends across the entire installation. Data from these studies were compiled and analyzed, and recommendations were made regarding future monitoring and management of the golden-cheeked warbler population on Fort Hood, Texas. 


\section{Mode of Technology Transfer}

This research contributes to a fundamental understanding of the ecology of the endangered golden-cheeked warbler, and serves as an example of a proactive approach to endangered species management on Army lands. This and other related reports are being transmitted to military, land, and wildlife managers at Fort Hood, Texas; The Army Environmental Center (AEC); and the Department of the Army for use in ESA and NEPA compliance efforts. This report will also be made accessible through the World Wide Web (WWW) at URL: http://www.cecer.army.mil. 


\section{Methods}

\section{Establishing a New GCW Study Area}

The Nature Conservancy has three Intensive Study Areas (ISAs) located on Fort Hood, Texas, where GCW population monitoring has been ongoing since 1992 (Peak 2005). Demographic data such as territory size and density, age structure, mated status, males producing $\geq 1$ fledgling, and nest monitoring data have been gathered each year since then. This data can be used to monitor population changes over time and to estimate possible causes in the increase/decrease of a population (DeSante and Rosenberg 1998, Manley 1993). Data collected in the ISAs are used to extrapolate GCW demographics across the entire extent of the habitat available on Fort Hood, and give a picture of what is happening on the installation as a whole.

For this project researchers established a 1-year intensive study plot to provide baseline data for population status in an area with the potential to see increased military training activity. These efforts will also attempt to evaluate whether data from other research plots on Fort Hood, which have been intensely monitored, can be extrapolated to habitat areas that are currently undersampled. For the purpose of this study, TNC data from 2003-2006 were used in the comparison of the 1-year plot to the well studied areas. Because changes were made to the survey protocol prior to the start of the 2003 field season (Peak 2003), data from previous years were not included for this comparison.

\section{Study Plot}

The study area was located on the eastern part of Fort Hood, north of Cowhouse Creek and on the western edge of the Owl Creek Mountains. It was primarily located in the eastern part of Training Area (TA) 13, but also included the northwest part of TA 22 and the northern part of TA 21 (Figure 1). The study area encompassed 164 ha. 


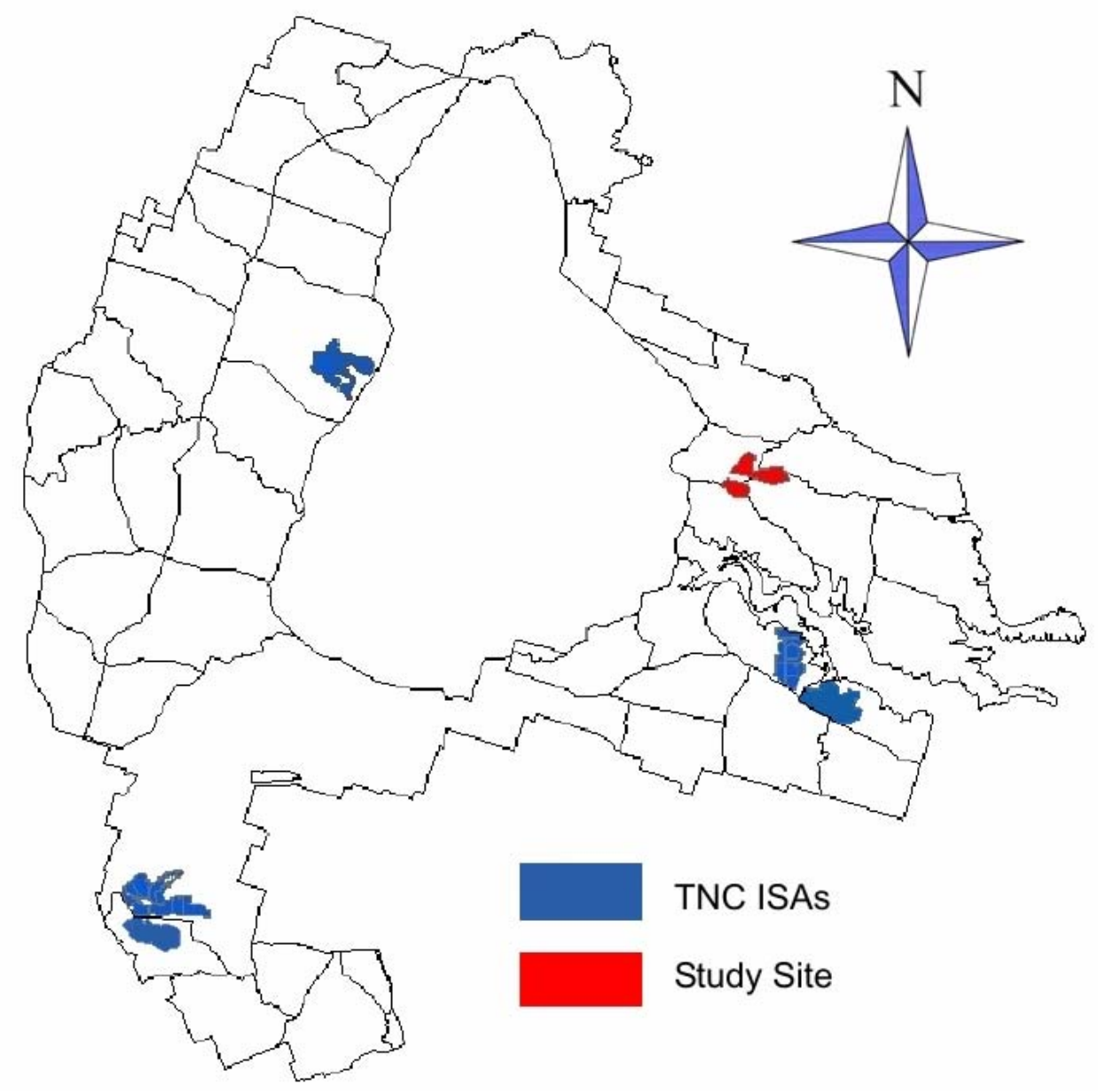

Figure 1. TNC Intensive Study Areas and ERDC-CERL Study Area on Fort Hood, Texas.

\section{Territory Mapping/Observational Surveys}

Males observed/heard in a specific area over consecutive visits were considered to have an established territory and therefore were continuously monitored throughout the field season. Observations were made in each territory at least twice a week for approximately 1 hour each visit. Global Positioning System (GPS) locations in the form of Universal Transverse Mercator (UTM) coordinates, were taken for the targeted individual approximately 30 and 60 minutes into each visit using a Garmin $V$ handheld GPS receiver. Point locations of territorial males were taken approximately 
$30 \mathrm{~m}$ apart from one another. During survey periods all relevant behaviors of males/females/fledglings were recorded; including but not limited to: presence/absence of adults or fledglings, individuals seen with nesting materials, food delivery, and nest monitoring. Due to the inaccessibility of some areas of the study plot, some individuals were monitored at less frequent intervals than others.

\section{Banding}

Banding of individuals was initiated on 19 April and continued through the length of the field season, until 30 June. Banding attempts consisted of using mist nets, sound equipment including an MP3 digital audio player with speaker, appropriately sized U.S. Fish and Wildlife Service (USFWS) numbered aluminum bands and a variety of colored plastic leg bands. Nets were set up within a male's territory and individuals were attracted to the nets using a variety of recorded GCW songs and calls. Attempts lasted no longer than 15 minutes and no more than 5 netting attempts were conducted on an individual. Captured GCWs were fitted with a USFWS band along with a unique combination of color bands to allow for accurate subsequent identification of individuals at a distance. Age and sex of each individual GCW were recorded using guidelines from Pyle (1997), as well as appropriately refined guidelines (Tim Hayden, personal communication, Biologist, ERDC-CERL). All individuals were aged and placed in one of four categories: HY (hatch year), SY (second year), and ASY (after second year). When, after examining all useful characteristics, the age of a bird could not be determined, it was recorded as AHY (after hatch year). All nontarget species were extracted from the net and released without banding. UTM coordinates of all successful banding locations were recorded using a GPS receiver. Banding attempts were made for both adults and fledglings.

\section{Productivity}

While conducting the observational surveys researchers collected data on pairing success and the percent of territorial males producing one or more fledglings. A male was considered to be paired if a female was seen within the male's territory on at least three separate visits. A male was considered to have produced $\geq 1$ fledgling if researchers observed a male feeding fledglings or carrying food to an area in its territory when fledglings where known to be present. 
Nest searching was conducted on all monitored territories. Researchers attempted to determine the locations of nests using either behavioral cues from territorial adults or through systematic searches of territories suspected to contain a nest. When a nest was located and positively identified, a GPS location was taken and flagged at least $5 \mathrm{~m}$ away from the nest and monitored every 3 days. Monitoring was conducted as close to sunrise as possible to limit stress on the nesting pair and to gather information on status and stage of nest cycle. Information on hatching and fledging dates as well as behavior of adult birds was gathered.

\section{Data Analysis}

Territory density was calculated by dividing the number of territorial males found on the study by the total area of the study area. This assumes all territories are equal in size. Researchers calculated the approximate size of each territory by plotting the GPS points of each territorial male on a map of the landscape using ArcGIS 9; then using the polygon-drawing feature in ArcMap to draw a line around the cluster of observation coordinates associated with each male. This polygon represents a very rough estimate of each bird's territory based on the average of the boundary points. The software is able to calculate and map the exact area for each polygon representing a territory, but again this is only an estimate of the actual size and shape of territorial boundaries. The same method was used to calculate the area of the entire study plot.

To estimate mated success, the number of paired territorial males was divided by the total number of territorial males. If a female was observed within a male's territory on at least three occasions, the male was considered to be paired. Other date included the number of paired males that produced $\geq 1$ fledgling divided by the total number of territorial males and the total number of paired males. To estimate the number of fledglings per paired male, the total number of observed fledglings was divided by the number of paired males.

To calculate the age structure, the number of SY and ASY birds was divided by the total number of aged adults found within the study area. 


\section{Results}

Thirty territories were present on the 164-ha study area (18.3/100 ha). Territories ranged in size from 1.58 ha to 6.87 ha with an average territory size of 3.39 ha (95\% CI 2.89 ha - 3.89 ha; Figure 2). If territories were distributed evenly over the study area, overall territory density would be 1 territory per 5.46 ha or 0.18 territories per ha. But there was some overlapping (Figure 2).

Over the course of the field season, we banded 17 golden-cheeked warblers (Appendix 1), including 15 (88\%) territorial males and 2 (12\%) females. Of the 15 males, 12 (80\%) were ASY, and 3 (20\%) were SY (Figure 3). Of the 2 females, one was ASY (50\%) and one was AHY (50\%) due to indeterminate age characteristics. One previously banded male was located on the study area: RD/BL : OR/SI, USFWS 2310-93620.

Of the 30 monitored territorial males, 24 (80\%, 95\% CI 95.16-64.81\%) were paired. Of the 30 territorial males, 22 (73.33\%, 95\% CI 56.54 90.12\%) were successful in producing $\geq 1$ fledgling and out of the 24 paired males, 22 (91.67\%, 95\% CI 79.75\% - 100\%) were successful in producing $\geq 1$ fledgling. Sixty-four fledglings were observed, yielding an average of 2.13 (95\% CI 1.60 - 2.67) per territorial male, 2.67 (95\% CI 2.22 3.11) per paired male, and 2.91 (95\% CI $2.61-3.21$ ) per successful male.

Between the age classes the average fecundity was very similar for mated $\mathrm{SY}(\mathrm{n}=2)$ males was 3.0 young per paired SY. The average for paired ASY $(n=22)$ males was 2.64 young per paired ASY. Productivity between the age classes for successful SY $(n=2)$ males was the same at 3.0 but higher for successful ASY males at $2.9(n=20)$ per successful ASY male (Figure 4). These averages may be skewed due to small sample size. 


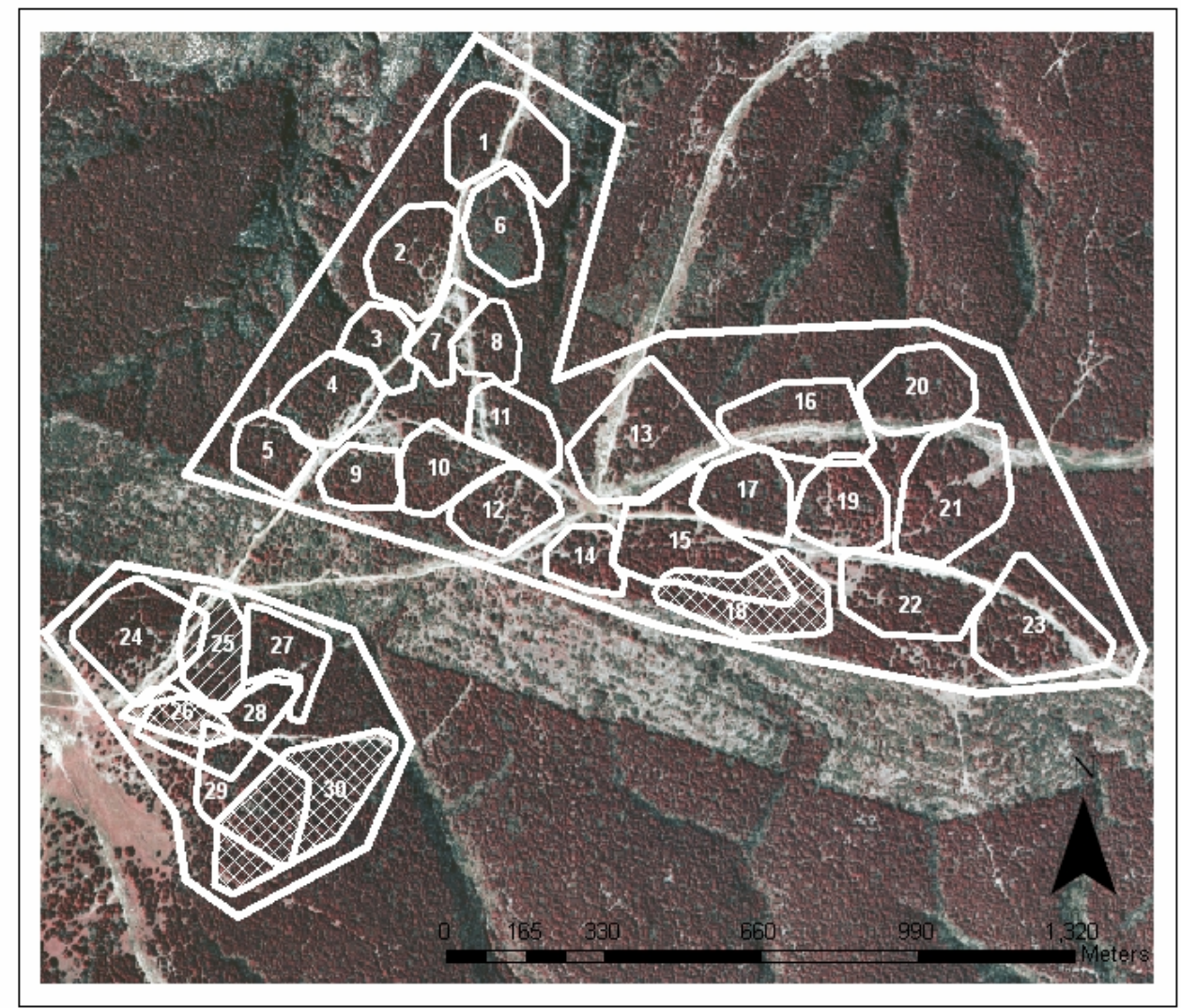

\begin{tabular}{|ccc|}
\hline Territory & Size (ha) & Mated Status \\
\hline 1 & 4.06 & $\mathrm{Y}$ \\
2 & 3.21 & $\mathrm{Y}$ \\
3 & 1.84 & $\mathrm{~N}$ \\
4 & 2.84 & $\mathrm{~N}$ \\
5 & 1.98 & $\mathrm{Y}$ \\
6 & 2.78 & $\mathrm{Y}$ \\
7 & 1.58 & $\mathrm{Y}$ \\
8 & 1.74 & $\mathrm{~N}$ \\
9 & 1.91 & $\mathrm{~N}$ \\
10 & 2.66 & $\mathrm{Y}$ \\
11 & 2.47 & $\mathrm{Y}$ \\
12 & 2.72 & $\mathrm{Y}$ \\
13 & 5.78 & $\mathrm{Y}$ \\
14 & 1.71 & $\mathrm{Y}$ \\
15 & 5.27 & $\mathrm{Y}$ \\
\hline
\end{tabular}

\begin{tabular}{|ccc|}
\hline Territory & Size (ha) & Mated Status \\
\hline 16 & 4.10 & $\mathrm{Y}$ \\
17 & 2.91 & $\mathrm{Y}$ \\
18 & 4.39 & $\mathrm{Y}$ \\
19 & 3.18 & $\mathrm{Y}$ \\
20 & 3.49 & $\mathrm{~N}$ \\
21 & 5.39 & $\mathrm{Y}$ \\
22 & 4.20 & $\mathrm{~N}$ \\
23 & 4.96 & $\mathrm{Y}$ \\
24 & 4.61 & $\mathrm{Y}$ \\
25 & 2.71 & $\mathrm{Y}$ \\
26 & 1.62 & $\mathrm{Y}$ \\
27 & 2.31 & $\mathrm{Y}$ \\
28 & 3.65 & $\mathrm{Y}$ \\
29 & 4.63 & $\mathrm{Y}$ \\
30 & 6.87 & $\mathrm{Y}$ \\
\hline
\end{tabular}

Figure 2. Territory size/location and mated status of territorial males on Study Area. Cross-hatching illustrates an overlap in territories and is used as a visual aid to distinguish continuous boundaries 


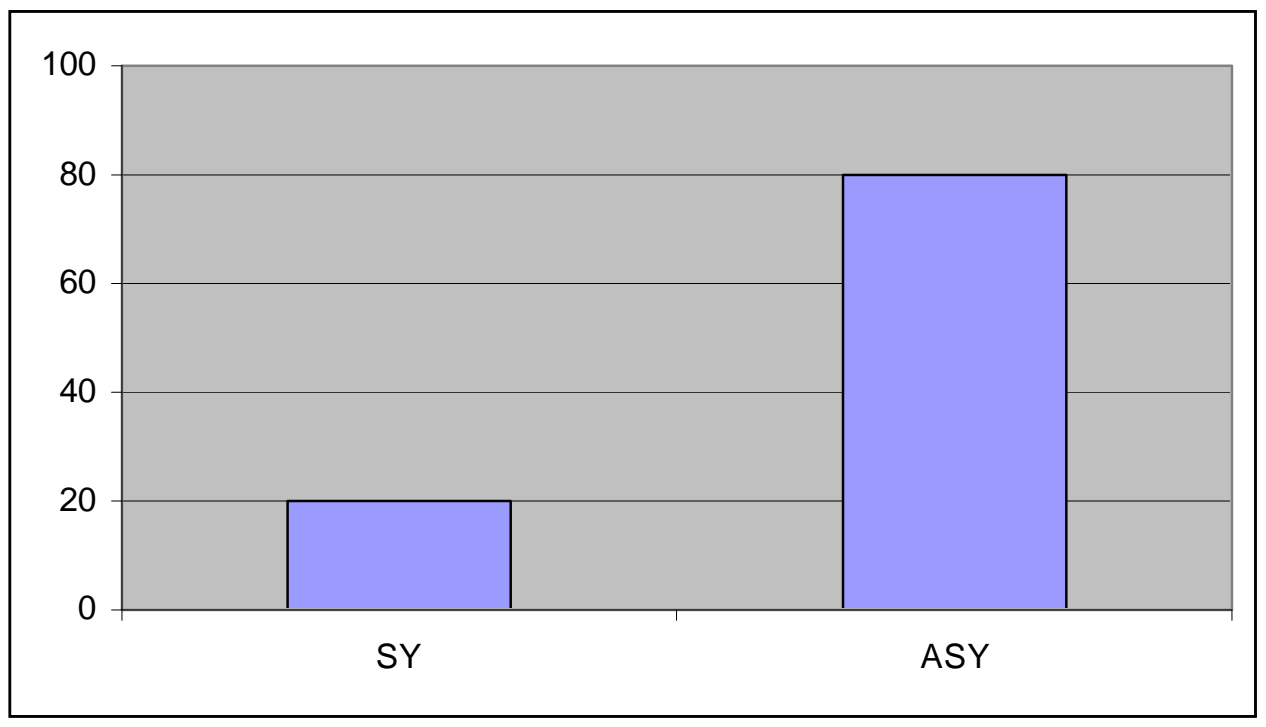

Figure 3. Age structure of banded territorial males on study area.

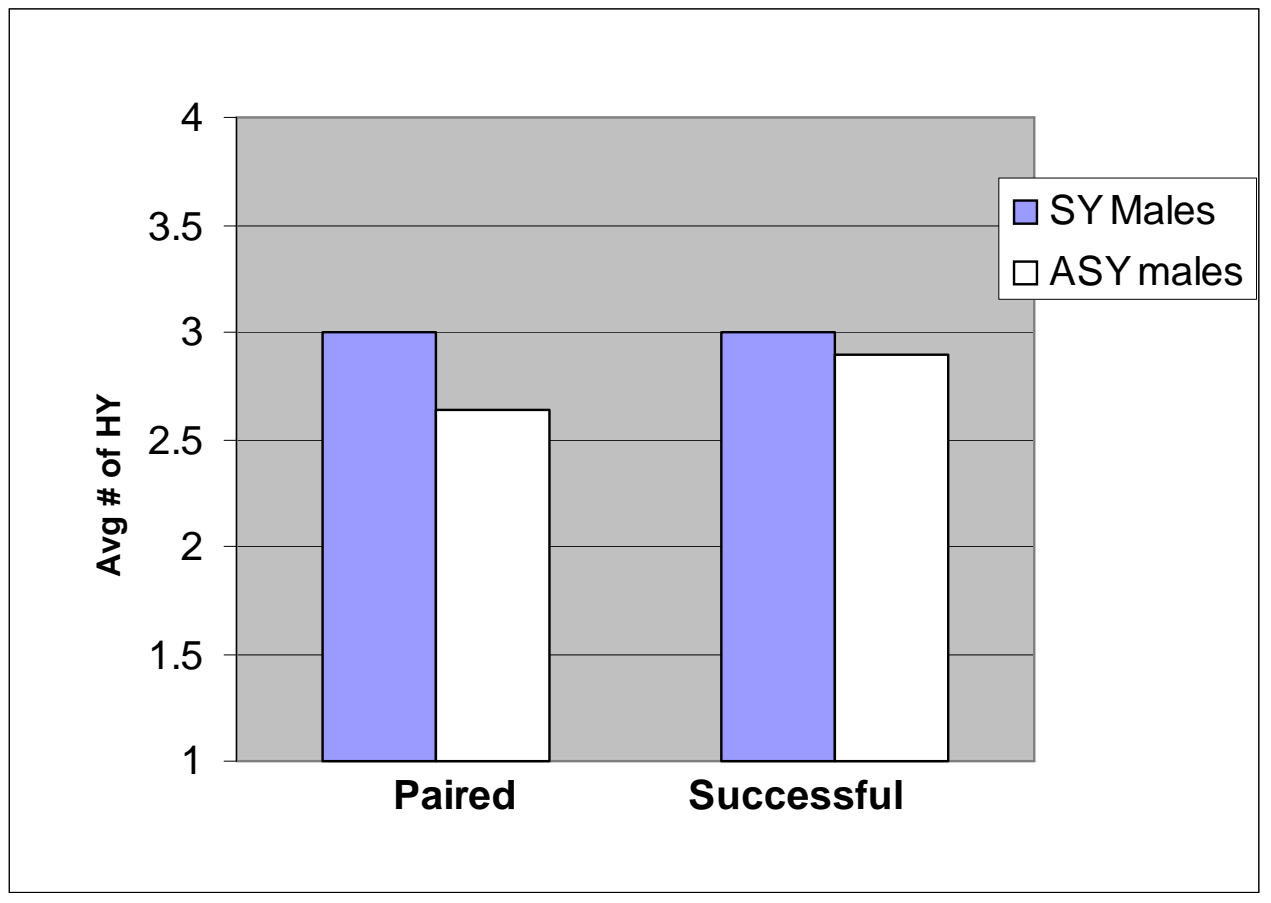

Figure 4. Productivity of SY territorial males and ASY territorial males. 
Two nests were found while monitoring territorial males in the study area. Both nests were monitored according to protocol. The first nest was discovered on 10 April 2006 and the young fledged on 8 May 2006. The nest contained 3 nestlings, which was the same number of fledglings observed being fed by both adults for at least 3 weeks within its territory. The second nest was found on 17 May 2006 with a female incubating. Observations were made of both adults feeding an unknown number of nestlings but the final outcome of the nest was unknown. The last observation was made on 5 June 2006 and an empty nest was found. Numerous attempts to locate the fledglings were unsuccessful. 


\section{Discussion}

Territory density was lower than those found on TNC's ISAs (2003-0.21 $\mathrm{N}=167 ; 2004-0.25 \mathrm{~N}=158 ; 2005-0.24 \mathrm{~N}=148 ; 2006-0.24 \mathrm{~N}=174$ ) (Table 1, Peak 2006). This may be the result of a lower number of territorial males due to habitat constraints (food, suitable nesting substrate, predators) or overall size of territories may have been larger than territories found on TNC's ISAs. Unfortunately TNC did not gather territory size data on each territorial male they monitored; therefore we cannot compare estimates. When comparing the current data to other studies, territory size collected in this study seems to fall somewhere in the middle of territory size estimates ( $0.81-2.55$ ha [Pulich 1976] and $4.44-8.48$ ha [Kroll 1980]). The fact that only 15 out of 30 males were banded within the study area may have lead to inaccurate identification of males. An over- or underestimation of the number of territory males could have occurred. The sample size is also considerably smaller than that collected by TNC, which allows for a higher rate of sampling error.

Table 1. Overall territory density.

\begin{tabular}{|l|l|}
\hline Study Area & Territory Density/ha \\
\hline TNC 2003 & 0.21 \\
\hline TNC 2004 & 0.25 \\
\hline TNC 2005 & 0.24 \\
\hline TNC 2006 & 0.24 \\
\hline Study Area 2006 & 0.18 \\
\hline
\end{tabular}

Pairing success was very similar (2003 - 82\%; $2004-78.4 \%$; $2005-$ 88.5\%; 2006 - 89\%; Figure 5; Peak 2006). A territorial male was classified as paired by having researchers observe a female on the territory at least three times. The protocol was a bit more stringent than TNC's, which considered a male paired if a female was observed on the territory only once (Peak 2005). However, the current pairing success rate would remain unchanged if the protocol was changed to match that observed by TNC. 


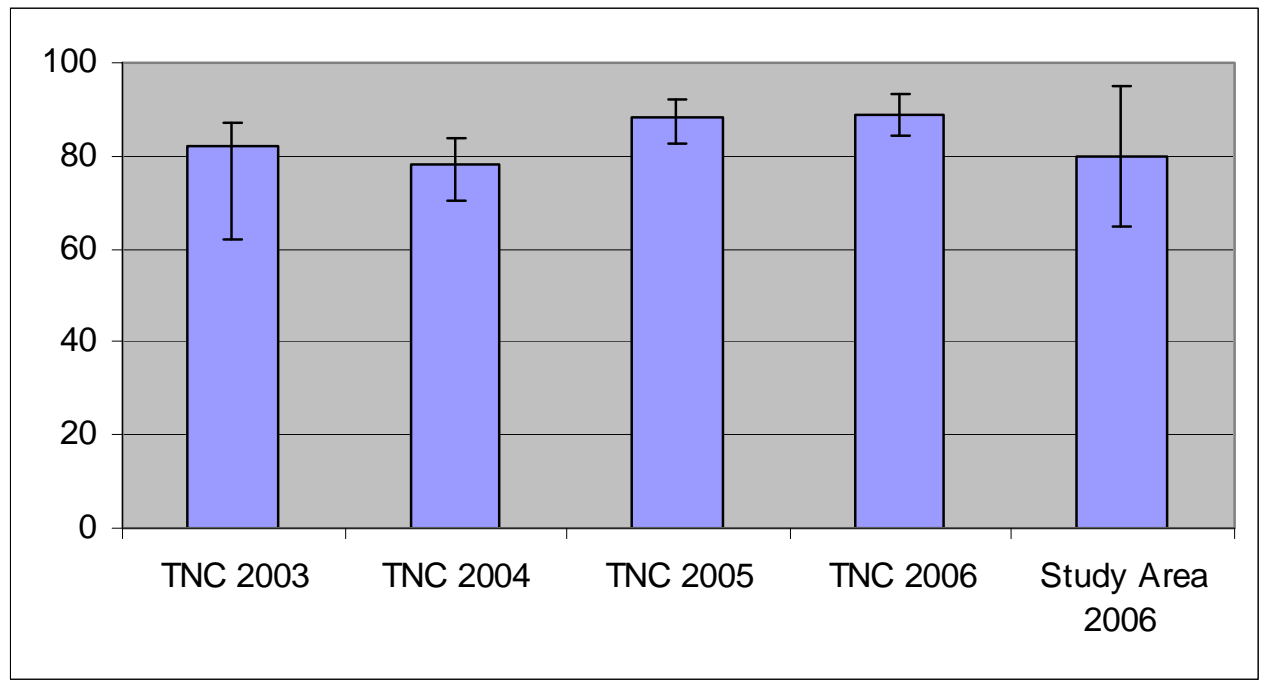

Figure 5. Pairing success of territorial males

The number of territorial males producing $\geq 1$ fledgling was considerably higher than TNC's estimates (2003 - 56.3\%; 2004 - 55.06\%; 2005 60.8\%; 2006 - 55.8\%; Figure 6; Peak 2006). The current protocol was the same as TNC's but possible inaccurate identification of non-banded males may have skewed the data. (When non-banded males live in adjacent territories, it is possible to observe the same male at varying times and locations and assume it was two or more different birds.) In previous studies, unmated males that have not produced any of their own fledglings have been observed feeding fledglings (Pekins 2002). These fledgling also form mobile groups that may venture beyond their delineated natal territories, further complicating identification.

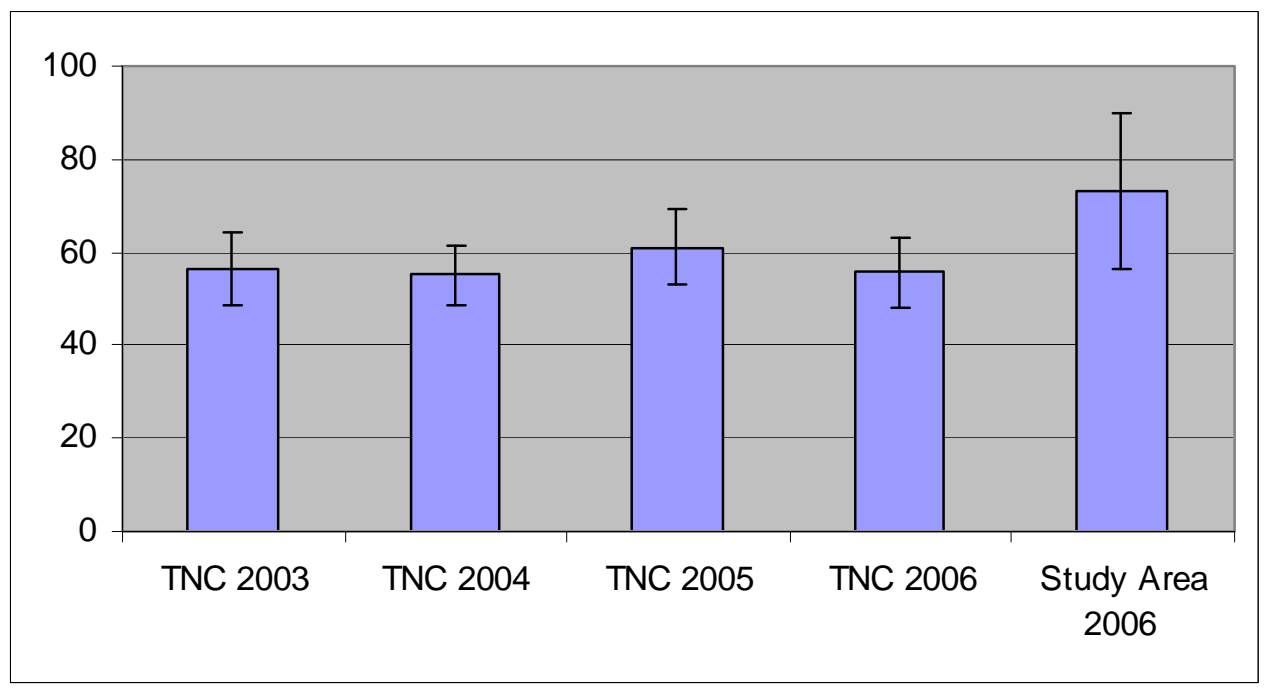

Figure 6. Number of territorial males producing $\geq 1$ fledgling. 
Age structure between study areas will not be compared. On TNC ISAs, banding has occurred for more than 10 yrs and there is historical information on the estimated age of many of the territorial males. For this study all males captured were not banded and thus could only be put into 2 categories (ASY and AHY).

In conclusion; this study supports the possibility of extrapolating TNC's data to areas on Fort Hood, Texas, that have not been intensively sampled. But considering the sample size, it may be necessary to compile additional years of data from this study site or others to gain a higher measure of confidence. It is also important to mention that the data collected was from the tops of mesas, because these are the areas that are most likely to be impacted due to the increase of military training. Data collected from slopes and the bottoms between mesas around Fort Hood may yield different results. Future work should include a protocol for sampling from these areas as well. 


\section{References}

Benson, R.H. 1990. Habitat area requirements of the Golden-cheeked Warbler on the Edwards Plateau. October 1990. Prepared for Texas Parks and Wildlife Department, Department of Engineering Technology, Texas A\&M University, College Station, TX.

DeSante, D. F., and D. K. Rosenberg. 1998. What do we need to monitor in order to manage andbirds? Pages 93-106 in J. M. Marzluff and R. Sallabanks, editors. Avian conservation: research and management. Island Press, Washington, D.C., USA.

Engels, T.M. 1995. The conservation biology of the Golden-cheeked Warbler (Dendroica chrysoparia). Ph.D. Dissertation, University of Texas, Austin.

Hayden, T.J., J.D. Cornelius, H.J. Weinberg, L.L. Jette, and R.H. Melton. 2001. Endangered species management plan for Fort Hood, Texas; FY01-05. Technical Report ERDC/CERL TR-01-26. Department of the Army, Engineer Research and Development Center, Construction Engineering Research Laboratory, Champaign, IL.

Jetté L. A., T. J. Hayden, J. D. Cornelius. 1998. Demographics of the Golden-cheeked Warbler (Dendroica chrysoparia) on Fort Hood, Texas. U.S. Army Construction Engineering Research Laboratories Technical Report 98/52, Champaign, Illinois.

Kroll J. C. 1980. Habitat requirements of the golden-cheeked warbler: management implications. Journal of Range Management. 33:60-65.

Manley, P. 1993. USDA Forest Service goals and programs for monitoring Neotropical migratory birds. Pages 252-257 in D. M. Finch and P. W. Stangel, editors. Status and management of Neotropical migratory birds. USDA Forest Service, General Technical Report, RM-GTR-229.

Peak, R. G. 2003. Demography of the golden-cheeked warbler on Fort Hood, Texas, 2005. In Endangered species monitoring and management at Fort Hood, Texas: 2005 annual report. The Nature Conservancy, Fort Hood Project, Fort Hood, Texas, USA.

Peak, R. G. 2005. Demography of the golden-cheeked warbler on Fort Hood, Texas, 2005. In Endangered species monitoring and management at Fort Hood, Texas: 2005 annual report. The Nature Conservancy, Fort Hood Project, Fort Hood, Texas, USA.

Peak, R. G. 2006. Demography of the golden-cheeked warbler on Fort Hood, Texas, 2005. In Endangered species monitoring and management at Fort Hood, Texas: 2005 annual report. The Nature Conservancy, Fort Hood Project, Fort Hood, Texas, USA. 
Pekins, C. E. 2002. Mountain biking impacts and demographic monitoring of the goldencheeked warbler at Fort Hood, Texas in 2002. In Endangered species monitoring and management at Fort Hood, Texas: 2002 annual report. The Nature Conservancy, Fort Hood Project, Fort Hood, Texas, USA.

Pulich, W.M. 1976. The Golden-cheeked Warbler: a bioecological study. Texas Parks and Wildlife Department. Austin, TX. 172 pp.

Pyle, P. 1997. Identification guide to North American Birds, Part I. Slate Creek Press, Bolinas, California, USA.

Tazik, D.J. and J.D. Cornelius. 1993. Status of the Black-capped Vireo at Fort Hood, Texas, Volume III: Population and nesting ecology. USACERL Technical Report EN-94/o1, Vol. III. 106 pp.

U.S. Fish and Wildlife Service. 1996. Golden-cheeked Warbler population and habitat viability assessment report. Compiled and edited by Carol Beardmore, Jeff Hatfield, and Jim Lewis in conjunction with workshop participants. Report of an Aug. 21-24, 1996 workshop arranged by the U.S. Fish and Wildlife Service in partial fulfillment of U.S. National Biological Service Grant No. 80333-1423. Austin, Texas. xii $+48 \mathrm{pp}+$ Appendix.

Wahl, R., D.D. Diamond, and D. Shaw. 1990. The golden-cheeked warbler: a status review. U.S. Fish and Wildlife Service, Ecological Services Office, Austin, Texas. 


\section{Appendix A: Banding Data}

\begin{tabular}{|l|l|l|l|l|l|l|}
\hline Band No. & Color Comb. & Age & Sex & Date & \multicolumn{2}{l|}{ Location (UTM) } \\
\hline $2410-77001$ & BL/BK:NB/SI & ASY & M & $4 / 19 / 2006$ & 631966 & 3455162 \\
\hline $2410-77002$ & OR/RD:NB/SI & AHY & M & $4 / 21 / 2006$ & 633314 & 3455221 \\
\hline $2410-77006$ & BK/BL:NB/SI & ASY & M & $4 / 25 / 2006$ & 631950 & 3455155 \\
\hline $2410-77007$ & BK/WH:NB/SI & ASY & M & $4 / 25 / 2006$ & 632006 & 3455082 \\
\hline $2410-77008$ & BK/OR:NB/SI & ASY & M & $4 / 26 / 2006$ & 632537 & 3455525 \\
\hline $2410-77009$ & GR/OR:NB/SI & ASY & M & $4 / 26 / 2006$ & 632229 & 3455615 \\
\hline $2410-77010$ & GR/GR:NB/SI & ASY & M & $4 / 26 / 2006$ & 632627 & 3456132 \\
\hline $2410-77013$ & RD/BK:GR/SI & ASY & M & $4 / 27 / 2006$ & 633176 & 3455396 \\
\hline $2410-77014$ & NB/YE:WH/SI & SY & M & $5 / 1 / 2006$ & 632135 & 3454938 \\
\hline $2410-77015$ & RD/SI:NB/RD & ASY & M & $5 / 4 / 2006$ & 632170 & 3454938 \\
\hline $2410-77016$ & OR/OR:BL/SI & SY & M & $4 / 28 / 2006$ & 632608 & 3456303 \\
\hline $2410-77018$ & GR/WH:OR/SI & ASY & M & $5 / 15 / 2006$ & 632271 & 3455614 \\
\hline $2410-77019$ & BL/BL:GR/SI & ASY & M & $5 / 16 / 2006$ & 633573 & 3455640 \\
\hline $2410-77020$ & NB/YE:GR/SI & ASY & M & $5 / 16 / 2006$ & 633191 & 3455606 \\
\hline $2410-77021$ & WH/BL:NB/SI & ASY & F & $5 / 31 / 2006$ & 632205 & 3455557 \\
\hline $2410-77022$ & BK/BK:NB/SI & AHY & F & $6 / 2 / 2006$ & 633180 & 3455304 \\
\hline
\end{tabular}




\section{Appendix B: Observational Data on GCW Territories 1-30}




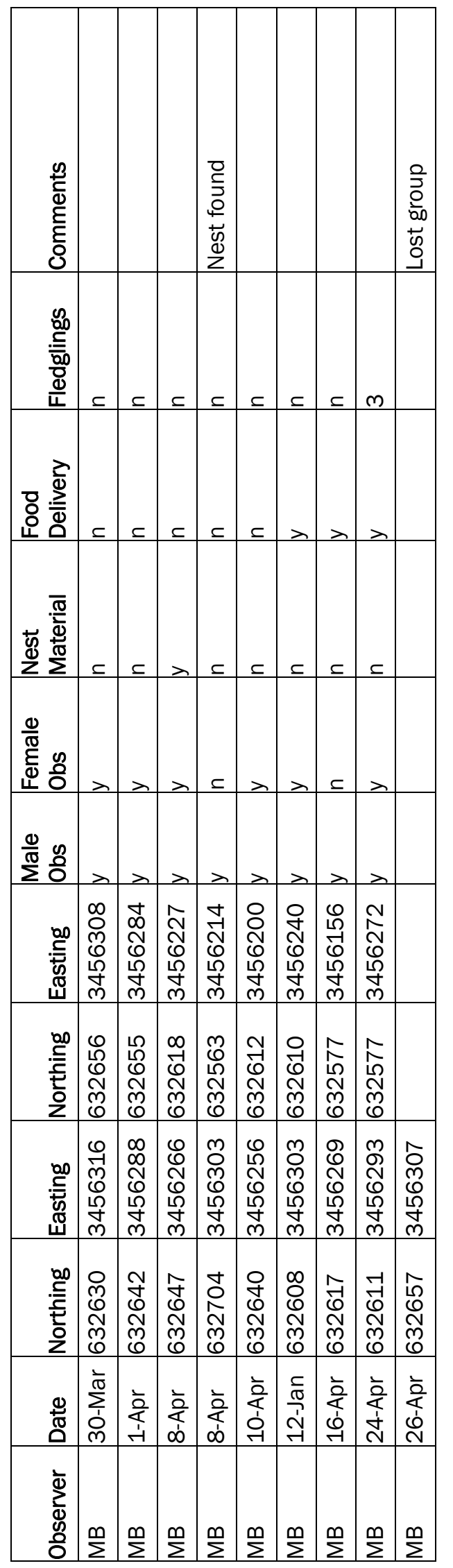

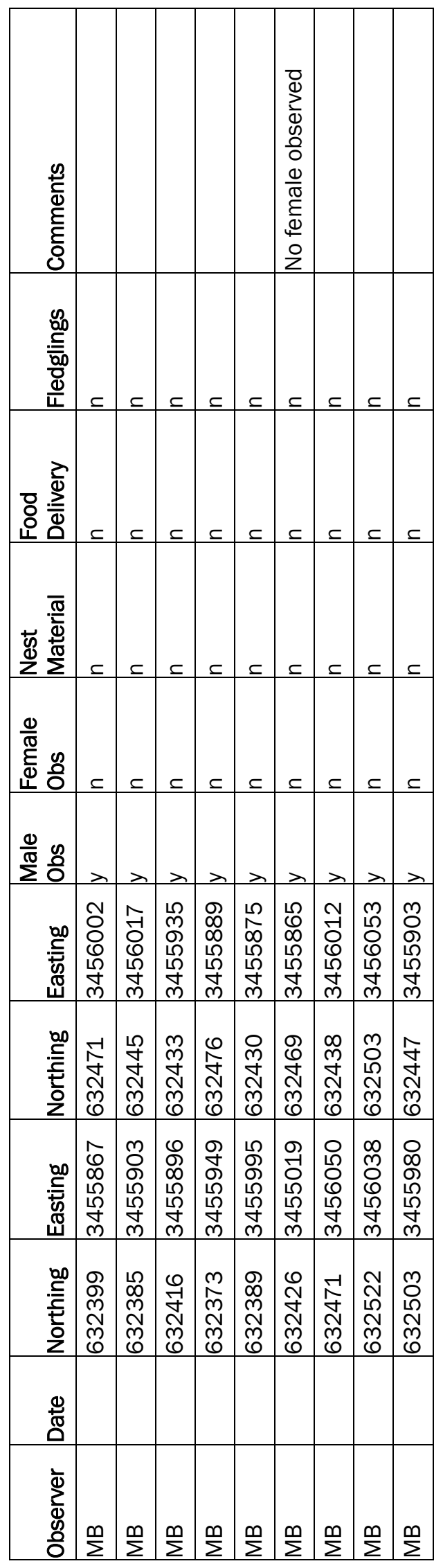




\begin{tabular}{|c|c|c|c|c|c|c|c|}
\hline 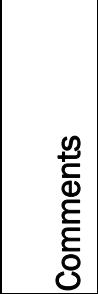 & & 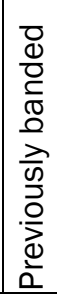 & & & & & \\
\hline 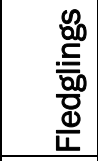 & $\subseteq$ & $\subseteq$ & $\subset$ & $\subset$ & $\subset$ & $\subseteq$ & $\subset$ \\
\hline 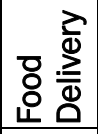 & $\subseteq$ & $\subseteq$ & $\subset$ & $\subset$ & $\subseteq$ & $\subseteq$ & $\subseteq$ \\
\hline 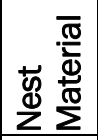 & $\subseteq$ & $\subseteq$ & $\subseteq$ & $\subseteq$ & $\subseteq$ & $\simeq$ & $\subset$ \\
\hline 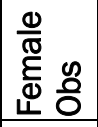 & $\subseteq$ & $\subseteq$ & $\subseteq$ & $\subseteq$ & $\subseteq$ & $\subseteq$ & $\subseteq$ \\
\hline$\frac{0}{\frac{0}{\pi}} \stackrel{0}{0}$ & $\lambda$ & $\lambda$ & $>$ & $>$ & $>$ & $>$ & $>$ \\
\hline 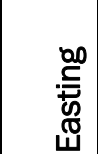 & 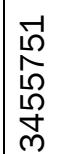 & 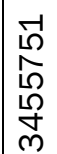 & 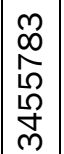 & \begin{tabular}{|l|} 
\\
$\infty$ \\
$\infty$ \\
1 \\
10 \\
$\tilde{m}$ \\
\end{tabular} & 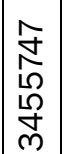 & 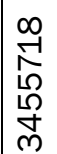 & 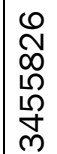 \\
\hline 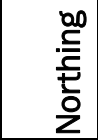 & 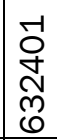 & 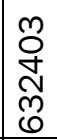 & 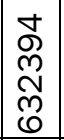 & 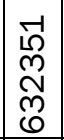 & \begin{tabular}{|l|}
$\infty$ \\
$\stackrel{\infty}{ }$ \\
$\stackrel{n}{ }$ \\
$\tilde{N}$ \\
0
\end{tabular} & $\begin{array}{l}\infty \\
\stackrel{\infty}{+} \\
\underset{\sim}{\sim} \\
0\end{array}$ & $\begin{array}{l}N \\
\infty \\
N \\
N \\
\tilde{N} \\
0\end{array}$ \\
\hline 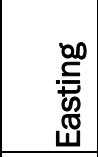 & $\begin{array}{l}0 \\
\text { 언 } \\
10 \\
10 \\
\text { m } \\
\end{array}$ & \begin{tabular}{l}
$\checkmark$ \\
\multirow{1}{*}{} \\
10 \\
10 \\
m \\
\end{tabular} & \begin{tabular}{|l|} 
\\
$\infty$ \\
$\infty$ \\
\llcorner \\
10 \\
1 \\
$m$ \\
\end{tabular} & \begin{tabular}{|l|} 
\\
$\infty$ \\
$\sim$ \\
$\Lambda$ \\
10 \\
$\tilde{m}$ \\
\end{tabular} & 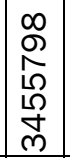 & 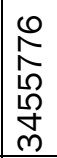 & $\begin{array}{l}9 \\
\infty \\
1 \\
10 \\
10 \\
1 \\
m \\
\end{array}$ \\
\hline 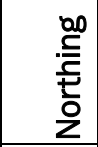 & $\begin{array}{l}\stackrel{2}{O} \\
\stackrel{+}{+} \\
\tilde{N} \\
0\end{array}$ & $\begin{array}{l}0 \\
0 \\
\tilde{N} \\
\tilde{N} \\
\tilde{0} \\
\end{array}$ & 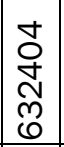 & \begin{tabular}{|l|}
$\overrightarrow{-}$ \\
$\stackrel{-}{+}$ \\
$\underset{\sim}{\tilde{C}}$ \\
\end{tabular} & $\begin{array}{l}\infty \\
\stackrel{\infty}{N} \\
\stackrel{N}{N} \\
\tilde{N} \\
0 \\
\end{array}$ & 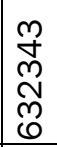 & $\begin{array}{l}\underset{\sim}{\checkmark} \\
\underset{\sim}{\sim} \\
0 \\
0\end{array}$ \\
\hline $\begin{array}{l}\stackrel{0}{ \pm} \\
\stackrel{0}{0}\end{array}$ & $\begin{array}{l}\frac{1}{\alpha} \\
0 \\
0 \\
+1\end{array}$ & 产 & 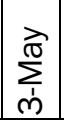 & 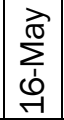 & 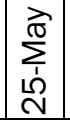 & 高 & 孚 \\
\hline 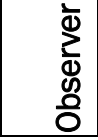 & $\stackrel{m}{\Sigma}$ & $\stackrel{m}{\Sigma}$ & $\stackrel{\mathscr{m}}{\Sigma}$ & $\stackrel{m}{\Sigma}$ & $\stackrel{m}{\Sigma}$ & $\stackrel{m}{\Sigma}$ & $\stackrel{m}{\Sigma}$ \\
\hline
\end{tabular}

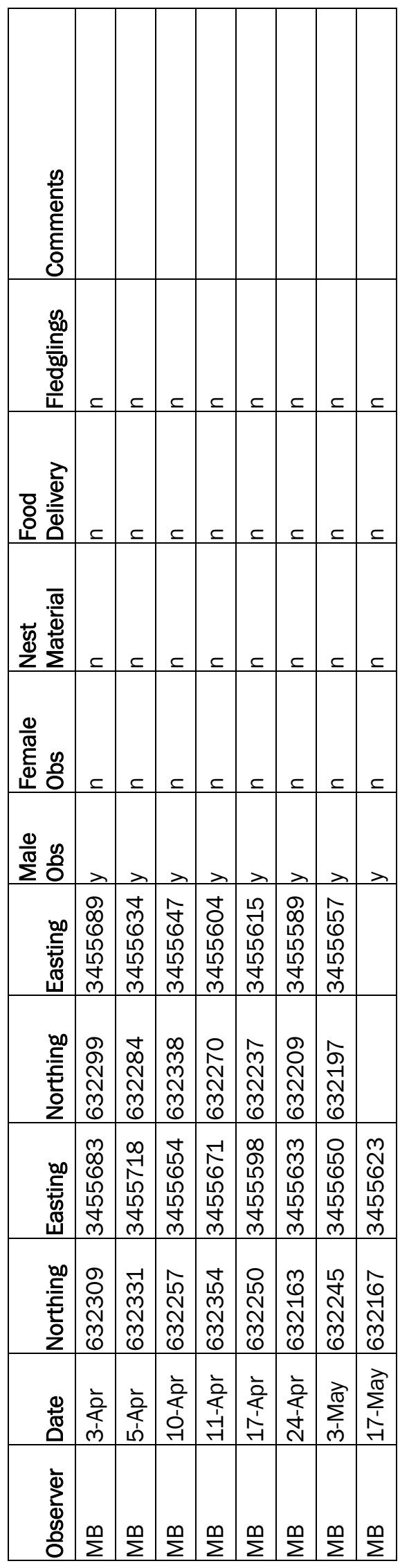




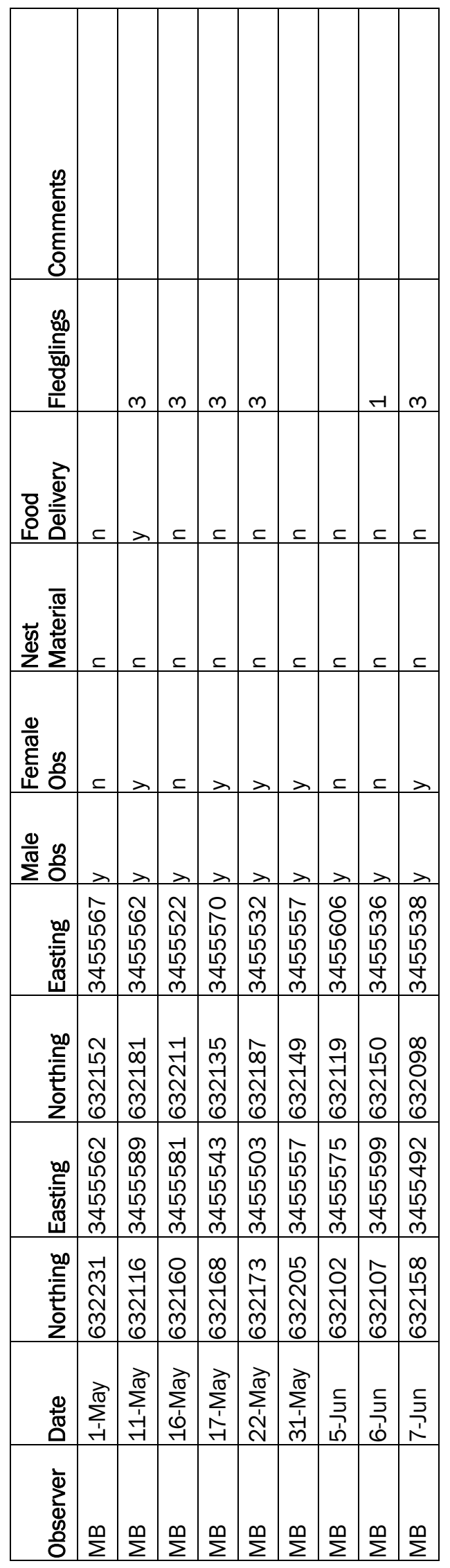

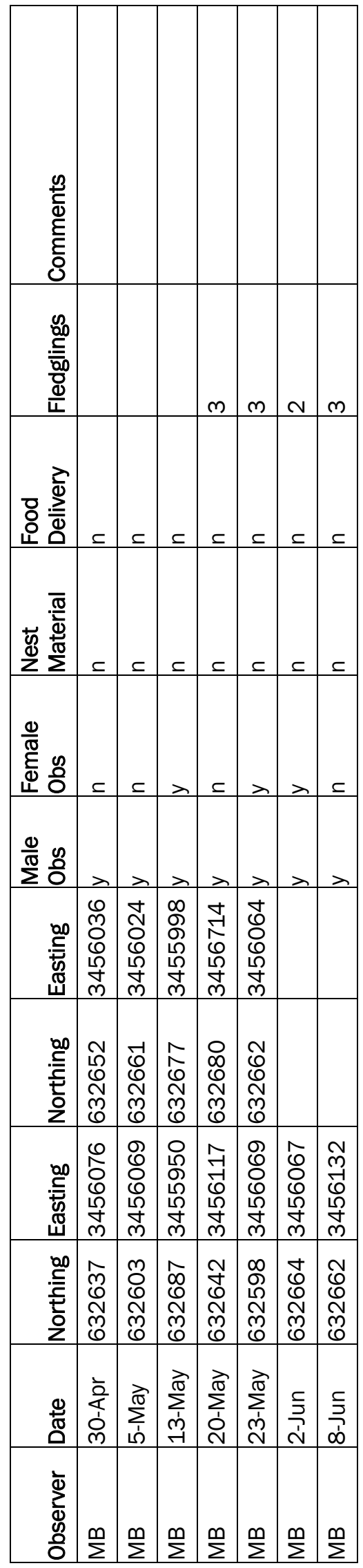




\begin{tabular}{|c|c|c|c|c|c|c|c|c|c|}
\hline 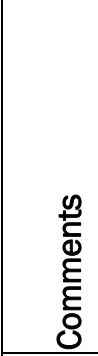 & & & & & 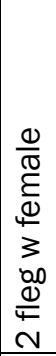 & & 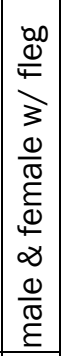 & & \\
\hline 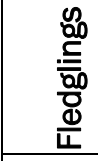 & & & & $\sim$ & $\sim$ & $\sim$ & $\sim$ & $\sim$ & $\sim$ \\
\hline 인 & $\subseteq$ & $\subseteq$ & $\simeq$ & $>$ & $>$ & 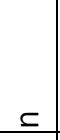 & $\simeq$ & $\simeq$ & $\subseteq$ \\
\hline 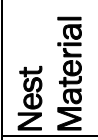 & $\subseteq$ & $\subseteq$ & $\subseteq$ & $\simeq$ & $\subset$ & $\subseteq$ & $\subseteq$ & $\subseteq$ & $\subseteq$ \\
\hline 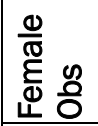 & $\subseteq$ & $\lambda$ & $\lambda$ & $\subseteq$ & 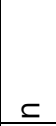 & $\subseteq$ & $>$ & $\subset$ & $\subset$ \\
\hline$\frac{\infty}{\frac{0}{\pi}} \stackrel{0}{2}$ & $\lambda$ & $\lambda$ & $\lambda$ & $>$ & $>$ & $>$ & $>$ & $>$ & $>$ \\
\hline 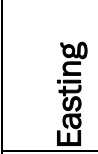 & 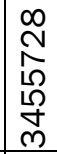 & $\begin{array}{l}0 \\
N \\
\infty \\
1 \\
10 \\
1 \\
\text { ஸे }\end{array}$ & $\begin{array}{l}\mathbf{1} \\
\infty \\
1 \\
10 \\
10 \\
\text { m }\end{array}$ & $\begin{array}{l}\hat{0} \\
0 \\
10 \\
10 \\
0 \\
\text { m }\end{array}$ & $\begin{array}{l}0 \\
\sim \\
\infty \\
1 \\
1 \\
1 \\
\tilde{m} \\
\end{array}$ & 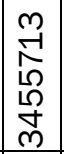 & \begin{tabular}{|l|} 
\\
0 \\
$\infty$ \\
1 \\
10 \\
1 \\
m \\
\end{tabular} & \begin{tabular}{l}
\multirow{0}{0}{} \\
0 \\
10 \\
10 \\
m \\
\end{tabular} & 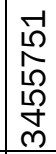 \\
\hline 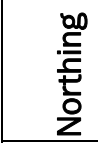 & $\begin{array}{l}\text { S } \\
\stackrel{D}{+} \\
\underset{N}{0} \\
0\end{array}$ & $\begin{array}{l}\mathcal{N} \\
\stackrel{+}{N} \\
\sim \\
N \\
0 \\
\end{array}$ & $\begin{array}{l}\mathcal{N} \\
N \\
N \\
N \\
0 \\
0\end{array}$ & 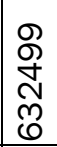 & 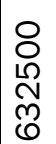 & $\mid \begin{array}{c}-1 \\
0 \\
10 \\
\sim \\
\tilde{0} \\
0\end{array}$ & $\begin{array}{c}0 \\
N \\
\hat{N} \\
N \\
N \\
0 \\
\end{array}$ & $\begin{array}{l}\text { D } \\
\stackrel{0}{ } \\
\stackrel{0}{0} \\
\tilde{N} \\
0\end{array}$ & \begin{tabular}{l}
$\mathcal{N}$ \\
$\infty$ \\
\multirow{N}{*}{} \\
$\widetilde{O}$ \\
0
\end{tabular} \\
\hline 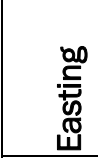 & 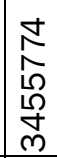 & 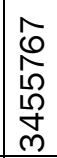 & $\begin{array}{l}\mathcal{N} \\
\text { N } \\
10 \\
\stackrel{1}{0} \\
\text { m }\end{array}$ & 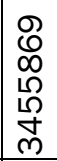 & 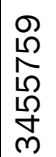 & 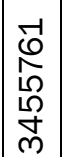 & 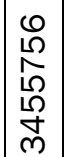 & 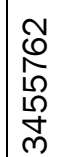 & 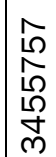 \\
\hline 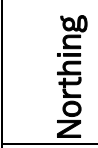 & $\begin{array}{l}0 \\
\stackrel{2}{+} \\
\sim \\
N \\
0\end{array}$ & \begin{tabular}{|l}
0 \\
0 \\
0 \\
$\mathbb{N}$ \\
$\tilde{N}$ \\
0
\end{tabular} & 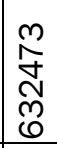 & $\begin{array}{c}N \\
\infty \\
1 \\
N \\
\tilde{N} \\
0\end{array}$ & 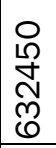 & 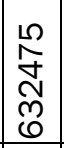 & 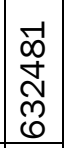 & $\begin{array}{l}\infty \\
\stackrel{N}{+} \\
\underset{\sim}{N} \\
\tilde{O}\end{array}$ & $\begin{array}{l}\stackrel{N}{\mathcal{Z}} \\
\underset{\sim}{\sim} \\
\underset{0}{0}\end{array}$ \\
\hline 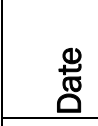 & 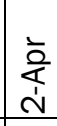 & 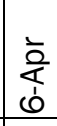 & 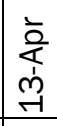 & 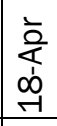 & 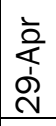 & \begin{tabular}{|l|}
$\sum_{i}^{\infty}$ \\
$\dot{j}$ \\
\end{tabular} & \begin{tabular}{|l|}
$\sum_{i}^{\infty}$ \\
0 \\
\end{tabular} & $\begin{array}{l}\sum_{i}^{\pi} \\
0 \\
-1 \\
-1\end{array}$ & $\begin{array}{l}\underset{\pi}{\pi} \\
\sum_{j}^{j} \\
\dot{d}\end{array}$ \\
\hline 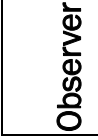 & $\stackrel{m}{\Sigma}$ & $\stackrel{m}{\Sigma}$ & $\stackrel{\varrho}{\Sigma}$ & $\stackrel{\mathscr{q}}{\Sigma}$ & $\stackrel{m}{\Sigma}$ & $\stackrel{m}{\Sigma}$ & $\stackrel{m}{\Sigma}$ & $\stackrel{\mathscr{m}}{\Sigma}$ & $\stackrel{m}{\Sigma}$ \\
\hline
\end{tabular}

\begin{tabular}{|c|c|c|c|c|c|}
\hline 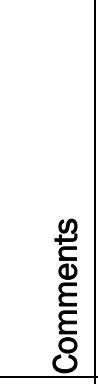 & & & & & \\
\hline 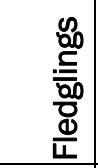 & $\subset$ & $\subseteq$ & $\subseteq$ & $\subset$ & $\subseteq$ \\
\hline ठ & $\subset$ & $\subseteq$ & $\subset$ & $\subset$ & $\subset$ \\
\hline 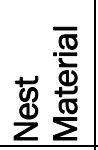 & $\subseteq$ & $\subseteq$ & $\subseteq$ & $\subseteq$ & $\subseteq$ \\
\hline 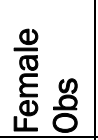 & $\subseteq$ & $\subseteq$ & $\subseteq$ & $\subset$ & $\subset$ \\
\hline$\frac{\mathscr{0}}{\sum^{\pi}} \stackrel{n}{\Sigma}$ & $\lambda$ & $\lambda$ & $>$ & $>$ & $\lambda$ \\
\hline 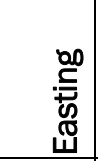 & $\begin{array}{l}0 \\
\infty \\
1 \\
1 \\
10 \\
\stackrel{0}{0} \\
\end{array}$ & 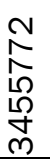 & 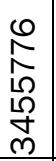 & 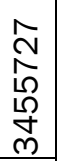 & 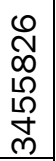 \\
\hline 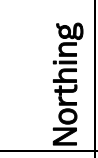 & \begin{tabular}{|l|} 
\\
0 \\
0 \\
$N$ \\
$\tilde{0}$ \\
\\
\end{tabular} & 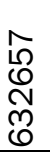 & $\begin{array}{l}\infty \\
N \\
\stackrel{N}{N} \\
\tilde{N} \\
0\end{array}$ & $\begin{array}{l}\mathscr{N} \\
\tilde{N} \\
0 \\
\tilde{N} \\
0\end{array}$ & 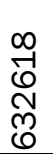 \\
\hline 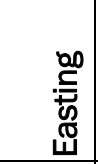 & 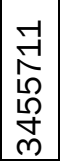 & 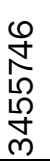 & 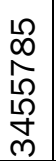 & 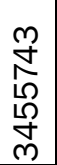 & 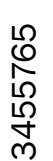 \\
\hline 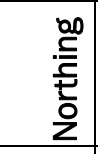 & \begin{tabular}{|c|}
0 \\
1 \\
$\sim$ \\
$N$ \\
$\tilde{0}$ \\
\end{tabular} & 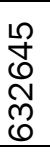 & 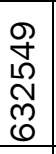 & 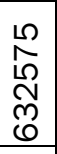 & $\begin{array}{l}\text { ㄱ. } \\
\stackrel{0}{ } \\
\text { गै } \\
0\end{array}$ \\
\hline $\begin{array}{l}\stackrel{0}{\pi} \\
0 \\
0\end{array}$ & 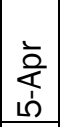 & $\begin{array}{l}\grave{2} \\
\frac{1}{1} \\
0\end{array}$ & 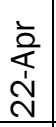 & $\begin{array}{l}\sum_{i}^{\vec{\pi}} \\
\dot{j} \\
\vec{j} \\
\end{array}$ & $\begin{array}{l}\sum_{\dot{d}}^{\vec{\sigma}} \\
\stackrel{i}{N} \\
\end{array}$ \\
\hline 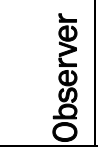 & $\stackrel{\varrho}{\Sigma}$ & $\sum_{\Sigma}^{m}$ & $\sum_{\Sigma}^{\infty}$ & $\stackrel{\mathfrak{m}}{\Sigma}$ & $\stackrel{\mathbf{m}}{\Sigma}$ \\
\hline
\end{tabular}




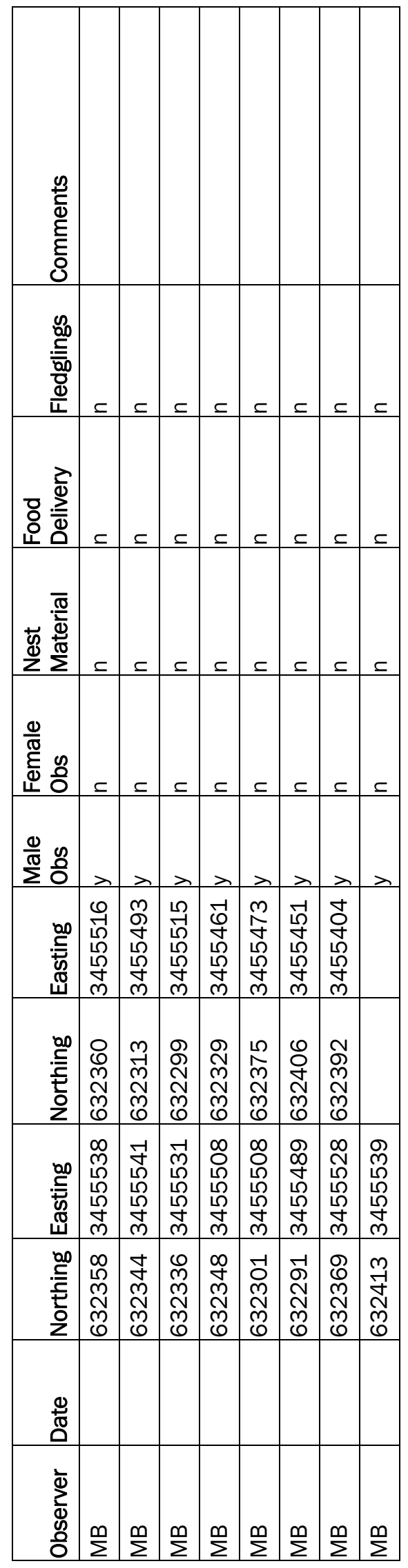

\begin{tabular}{|c|c|c|c|c|c|c|c|c|c|c|}
\hline 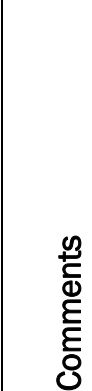 & & 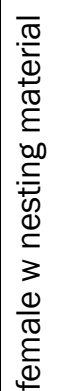 & & 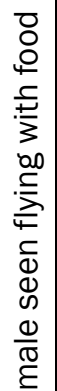 & & & & 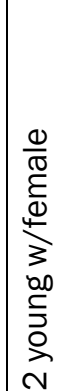 & & \\
\hline 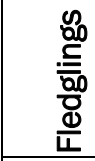 & & & & & & & & $N$ & $m$ & $m$ \\
\hline 인 & $\subseteq$ & $=$ & $\subseteq$ & $>$ & $=$ & $\subseteq$ & $=$ & $>$ & $>$ & $\subset$ \\
\hline 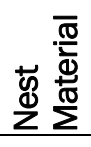 & $\subseteq$ & $\lambda$ & $\simeq$ & 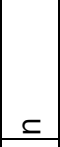 & $\simeq$ & 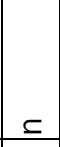 & $\subseteq$ & $\subset$ & $\subseteq$ & $\subseteq$ \\
\hline 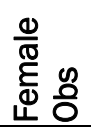 & $\lambda$ & $\lambda$ & $\lambda$ & $\subseteq$ & $\simeq$ & $\subseteq$ & $\subset$ & $\lambda$ & $\lambda$ & $\subset$ \\
\hline$\frac{\infty}{\infty} \frac{n}{0}$ & $\lambda$ & $\lambda$ & $>$ & $>$ & $\lambda$ & $>$ & $\lambda$ & $>$ & $>$ & $>$ \\
\hline 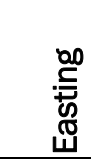 & 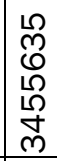 & 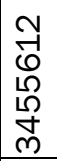 & 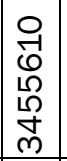 & 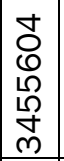 & 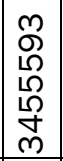 & 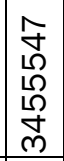 & \begin{tabular}{|l|}
$\infty$ \\
0 \\
0 \\
$\Lambda$ \\
$\Lambda$ \\
10 \\
m. \\
\end{tabular} & 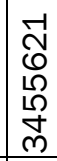 & 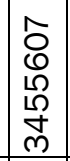 & 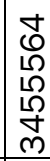 \\
\hline 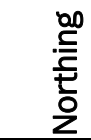 & $\begin{array}{l}0 \\
\stackrel{0}{ } \\
\mathscr{Q} \\
N \\
N \\
0 \\
\end{array}$ & \begin{tabular}{|l|} 
\\
0 \\
0 \\
0 \\
$N$ \\
$\tilde{0}$ \\
0
\end{tabular} & 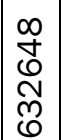 & \begin{tabular}{|c|}
$\tilde{n}$ \\
$\tilde{N}$ \\
0 \\
$\tilde{N}$ \\
0
\end{tabular} & 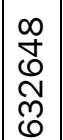 & \begin{tabular}{|c|} 
\\
10 \\
0 \\
0 \\
$\tilde{N}$ \\
0 \\
\end{tabular} & $\begin{array}{l}\mathcal{N} \\
\mathbb{N} \\
0 \\
N \\
\tilde{N}\end{array}$ & 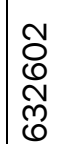 & $\begin{array}{l}8 \\
8 \\
N \\
\tilde{N} \\
0\end{array}$ & $\begin{array}{l}0 \\
N \\
N \\
N \\
0\end{array}$ \\
\hline 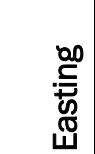 & 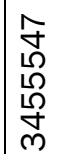 & 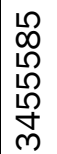 & 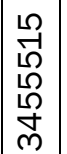 & $\begin{array}{l}\infty \\
01 \\
10 \\
10 \\
10 \\
\stackrel{1}{\infty} \\
\end{array}$ & \begin{tabular}{|l|} 
\\
8 \\
$\&$ \\
1 \\
10 \\
m \\
\end{tabular} & 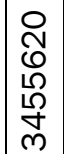 & 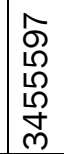 & 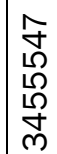 & 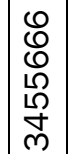 & 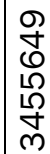 \\
\hline 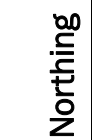 & 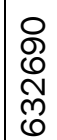 & $\begin{array}{l}\infty \\
\sim \\
\stackrel{\omega}{n} \\
\tilde{n} \\
0\end{array}$ & $\begin{array}{l}0 \\
\stackrel{0}{N} \\
N \\
N \\
\tilde{O}\end{array}$ & \begin{tabular}{|l|} 
\\
0 \\
$D$ \\
$N$ \\
$\tilde{N}$ \\
0
\end{tabular} & 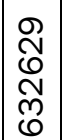 & 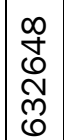 & $\begin{array}{l}\mathcal{N} \\
0 \\
0 \\
\mathcal{N} \\
\tilde{N} \\
0\end{array}$ & 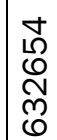 & $\begin{array}{l}\text { - } \\
\stackrel{م}{N} \\
\text { } \\
0\end{array}$ & 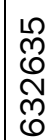 \\
\hline $\begin{array}{l}\frac{0}{\pi} \\
0\end{array}$ & $\begin{array}{l}\frac{1}{\pi} \\
\sum_{i}^{\infty} \\
-1 \\
M\end{array}$ & 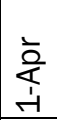 & 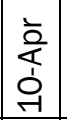 & \begin{tabular}{|l|} 
\\
$\frac{a}{T}$ \\
$\dot{1}$ \\
$\dot{H}$ \\
\end{tabular} & $\begin{array}{l}\bar{a} \\
\dot{a} \\
\dot{T} \\
\dot{\lambda} \\
\end{array}$ & 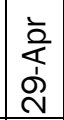 & $\sum_{i}^{\infty}$ & $\sum_{i}^{\stackrel{\pi}{a}}$ & 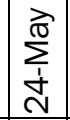 & $\begin{array}{l}5 \\
\stackrel{5}{2} \\
\end{array}$ \\
\hline $\begin{array}{l}\mathscr{y} \\
0 \\
0\end{array}$ & $\stackrel{m}{\Sigma}$ & $\stackrel{m}{\Sigma}$ & $\frac{m}{\Sigma}$ & $\stackrel{m}{\Sigma}$ & $\stackrel{\wp}{\Sigma}$ & $\stackrel{m}{\Sigma}$ & $\stackrel{m}{\Sigma}$ & $\stackrel{m}{\Sigma}$ & $\stackrel{m}{\Sigma}$ & $\sum^{\infty}$ \\
\hline
\end{tabular}




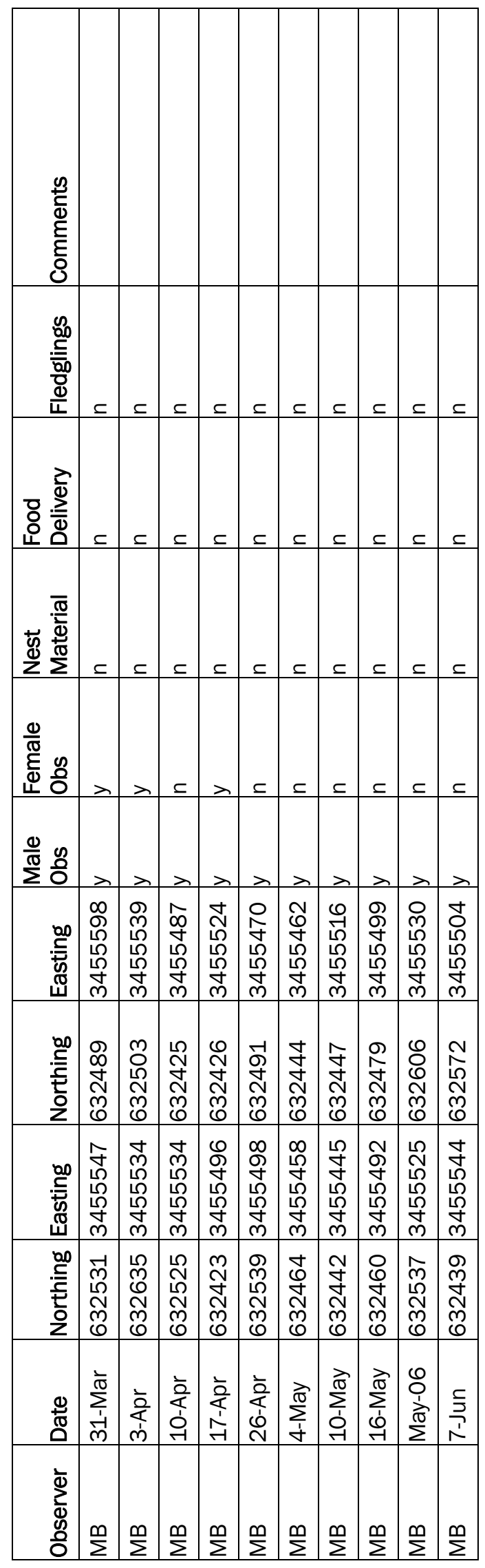

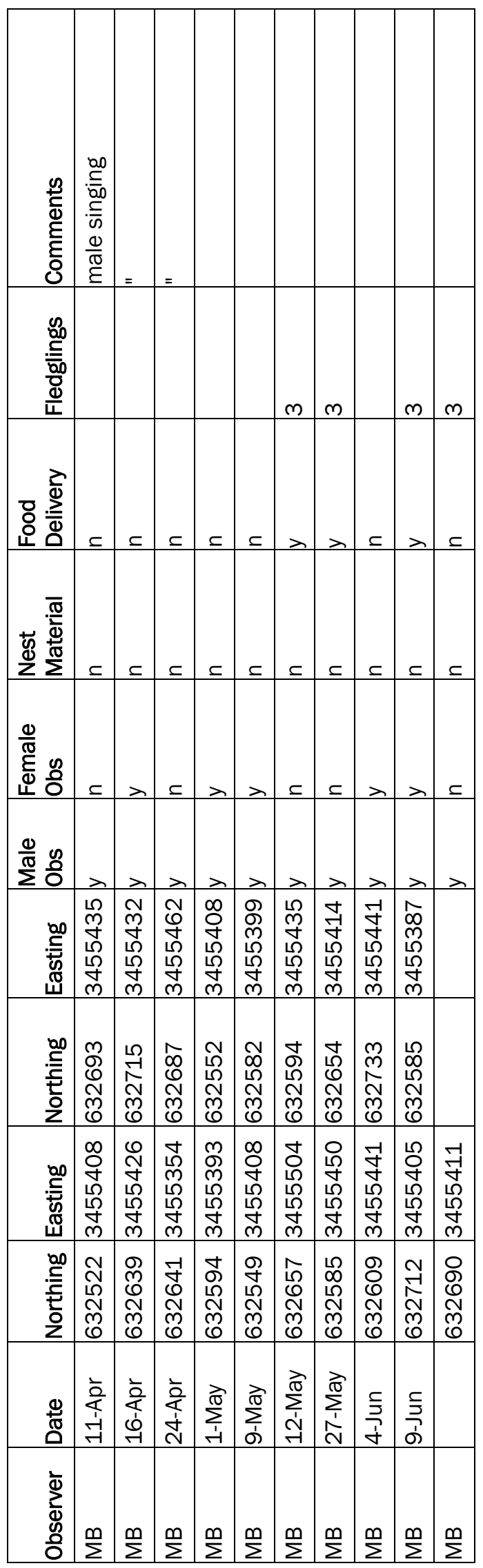




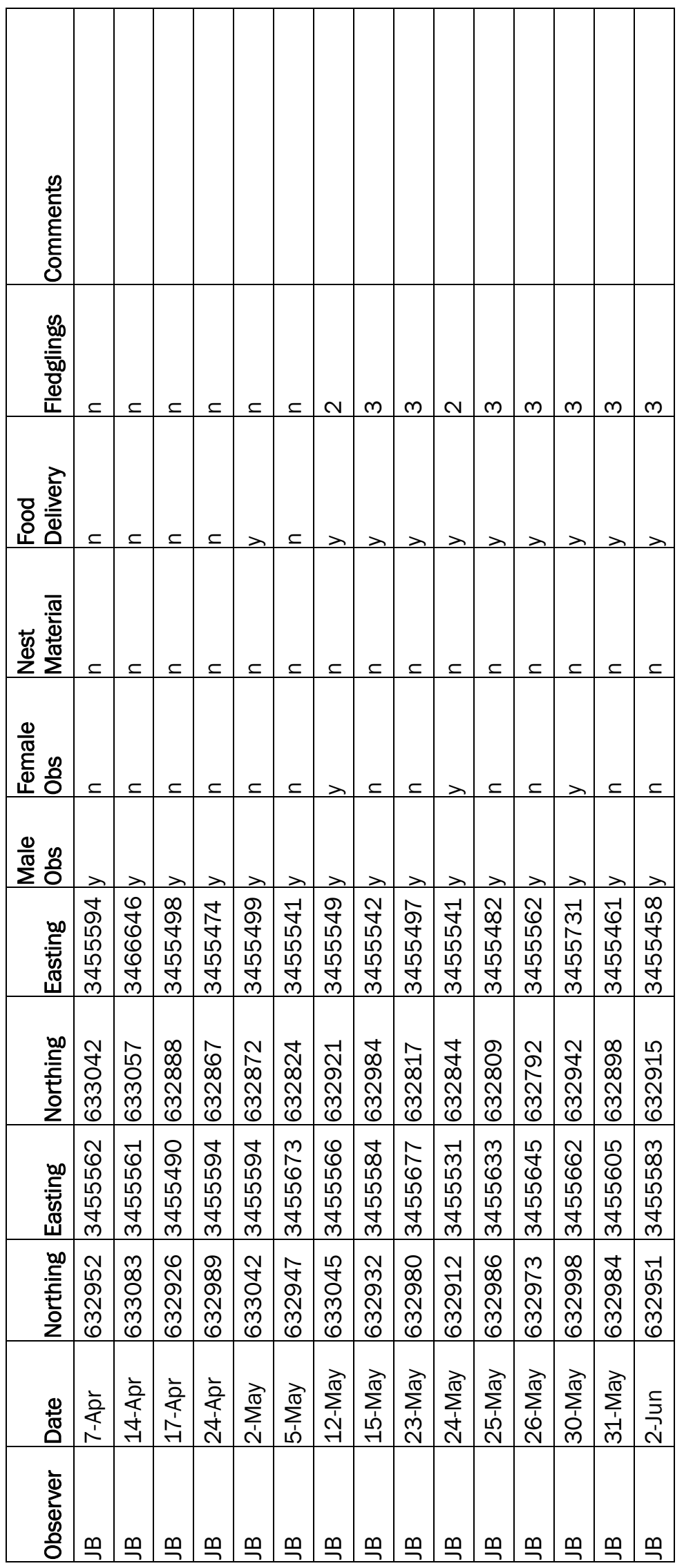




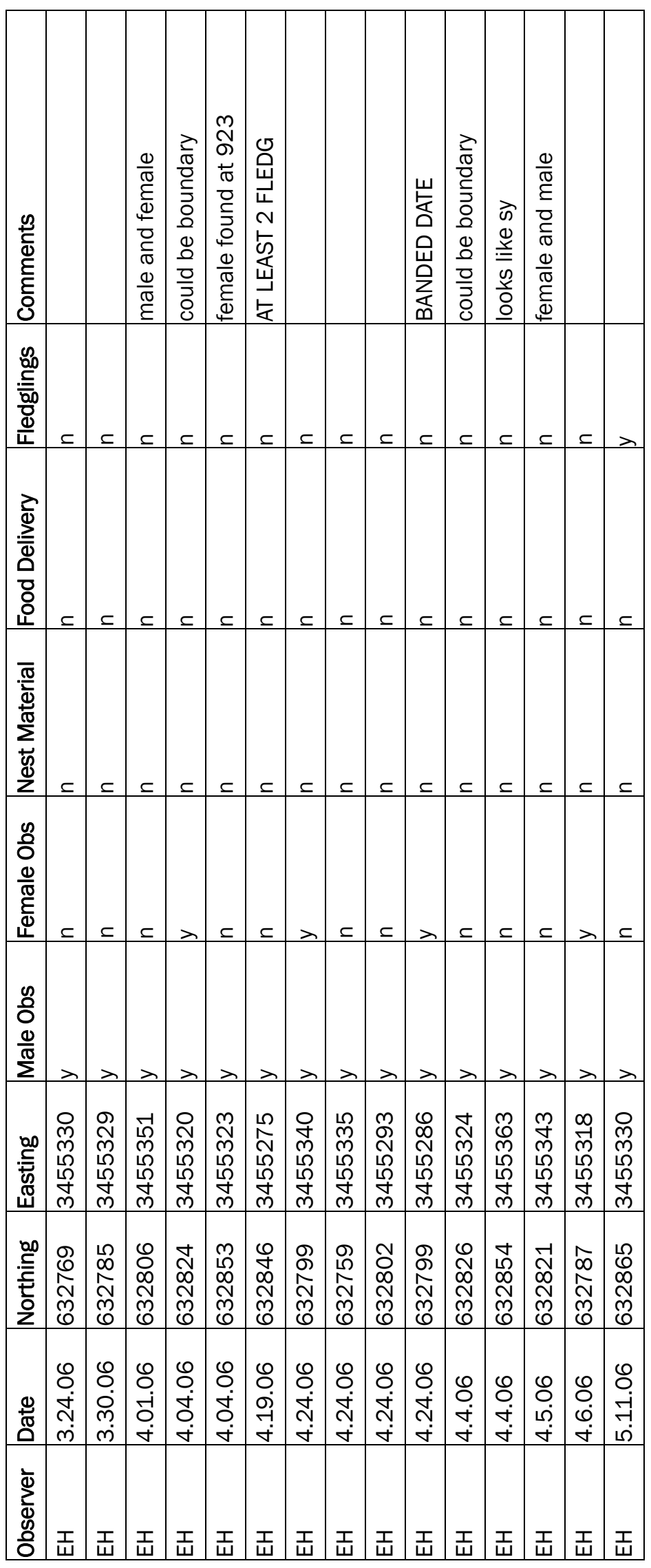




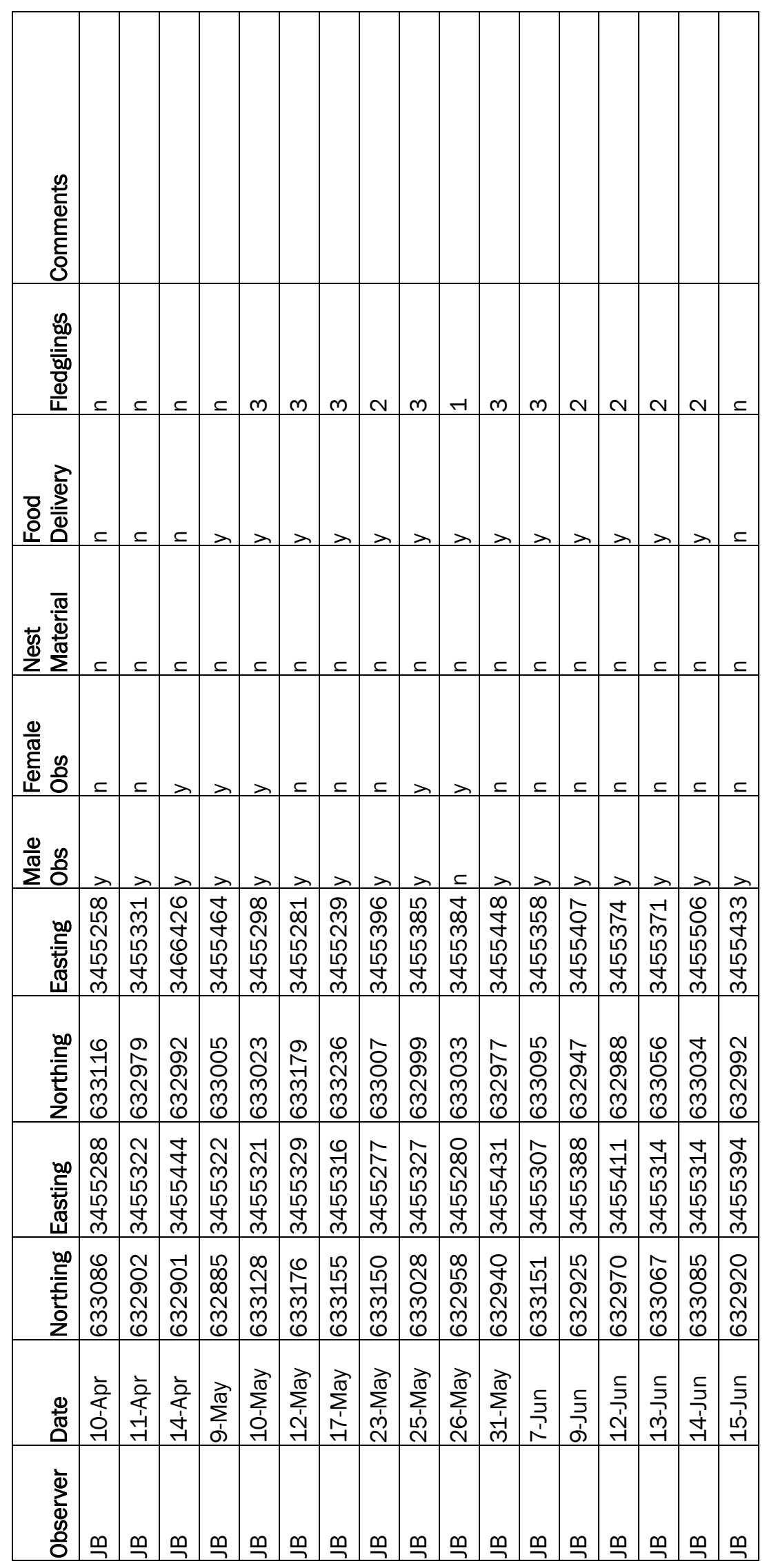




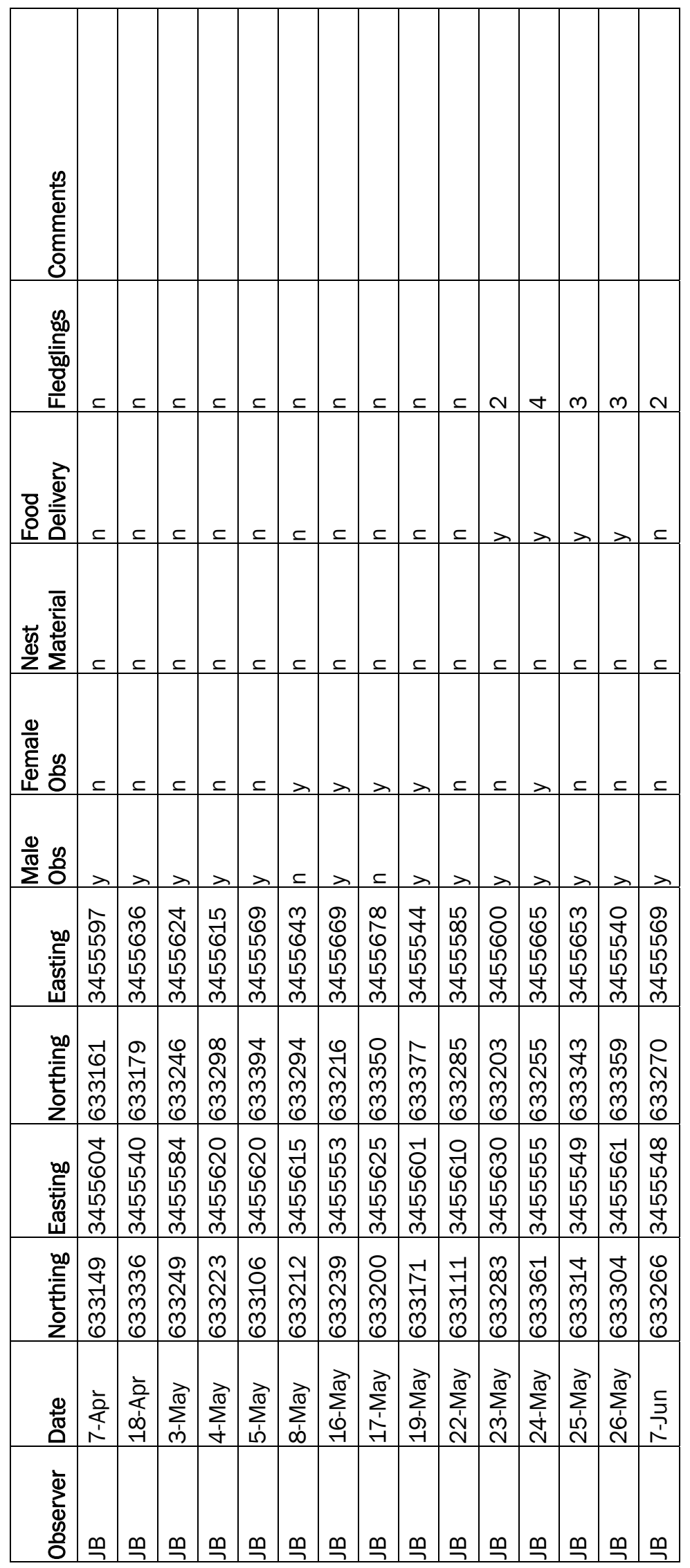




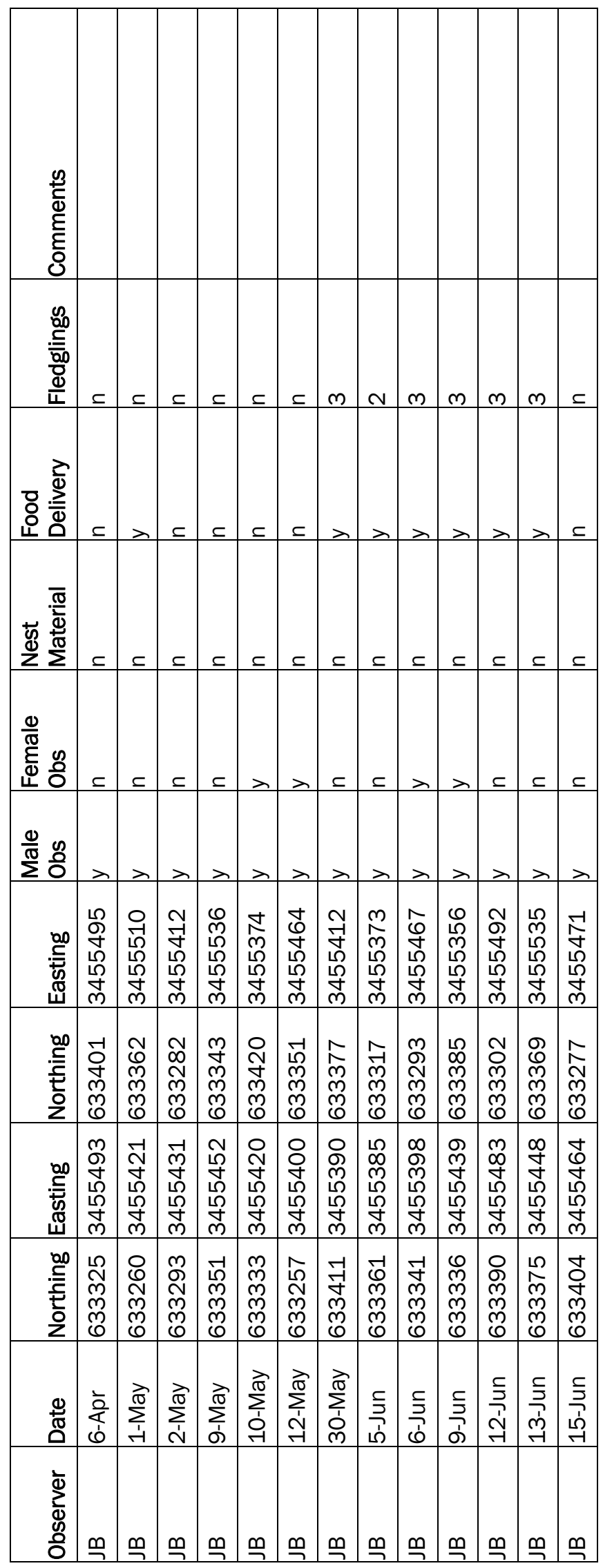




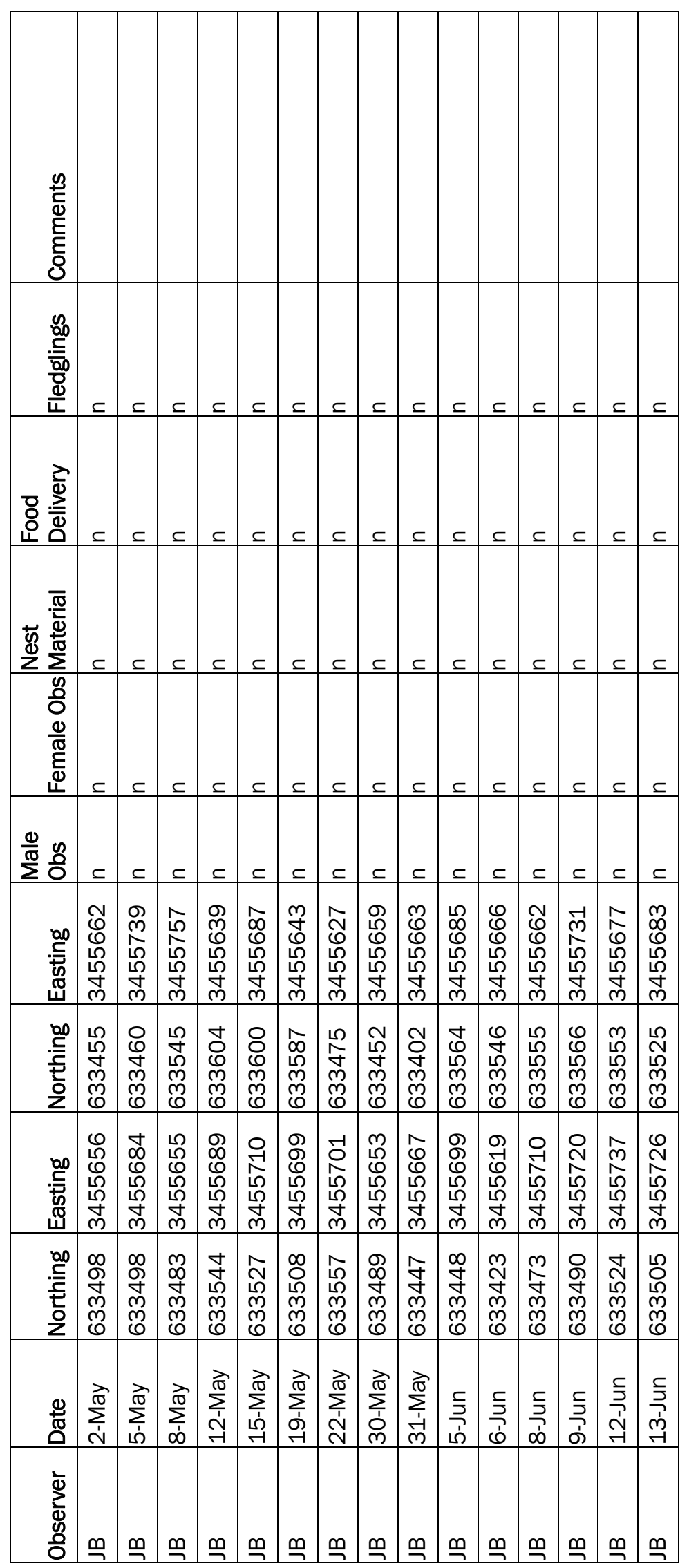




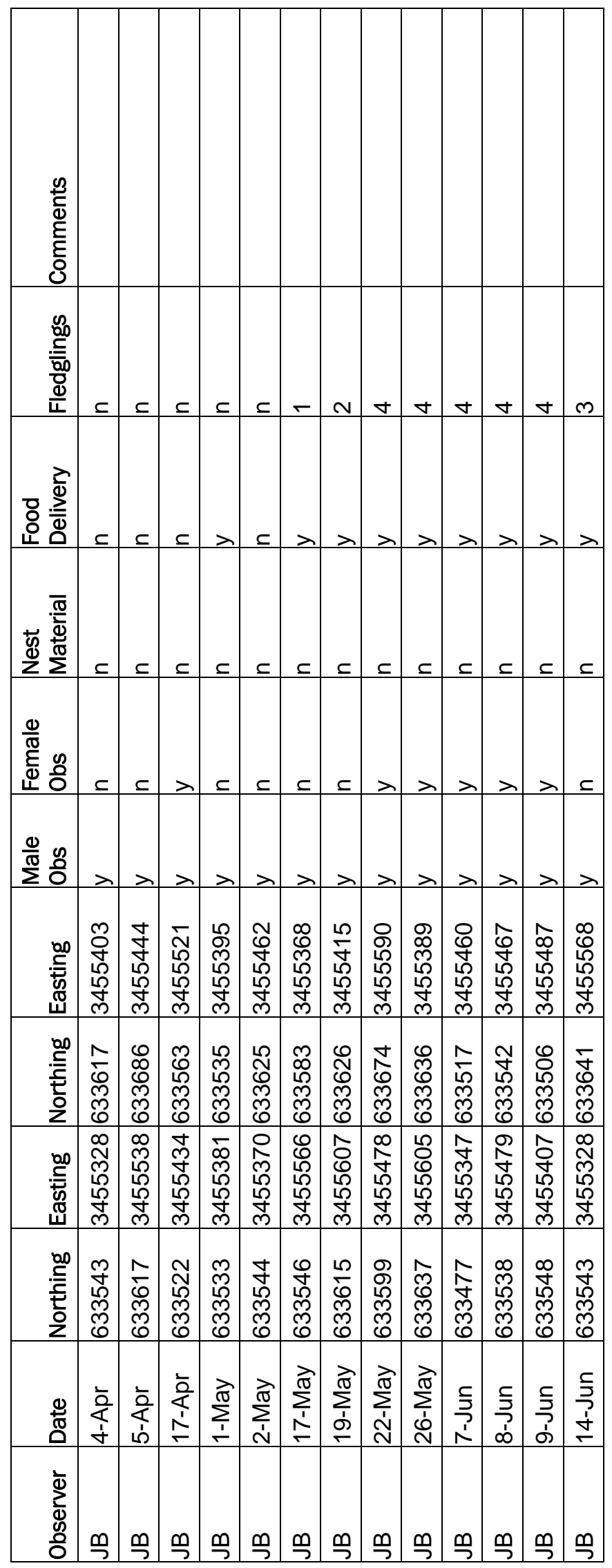




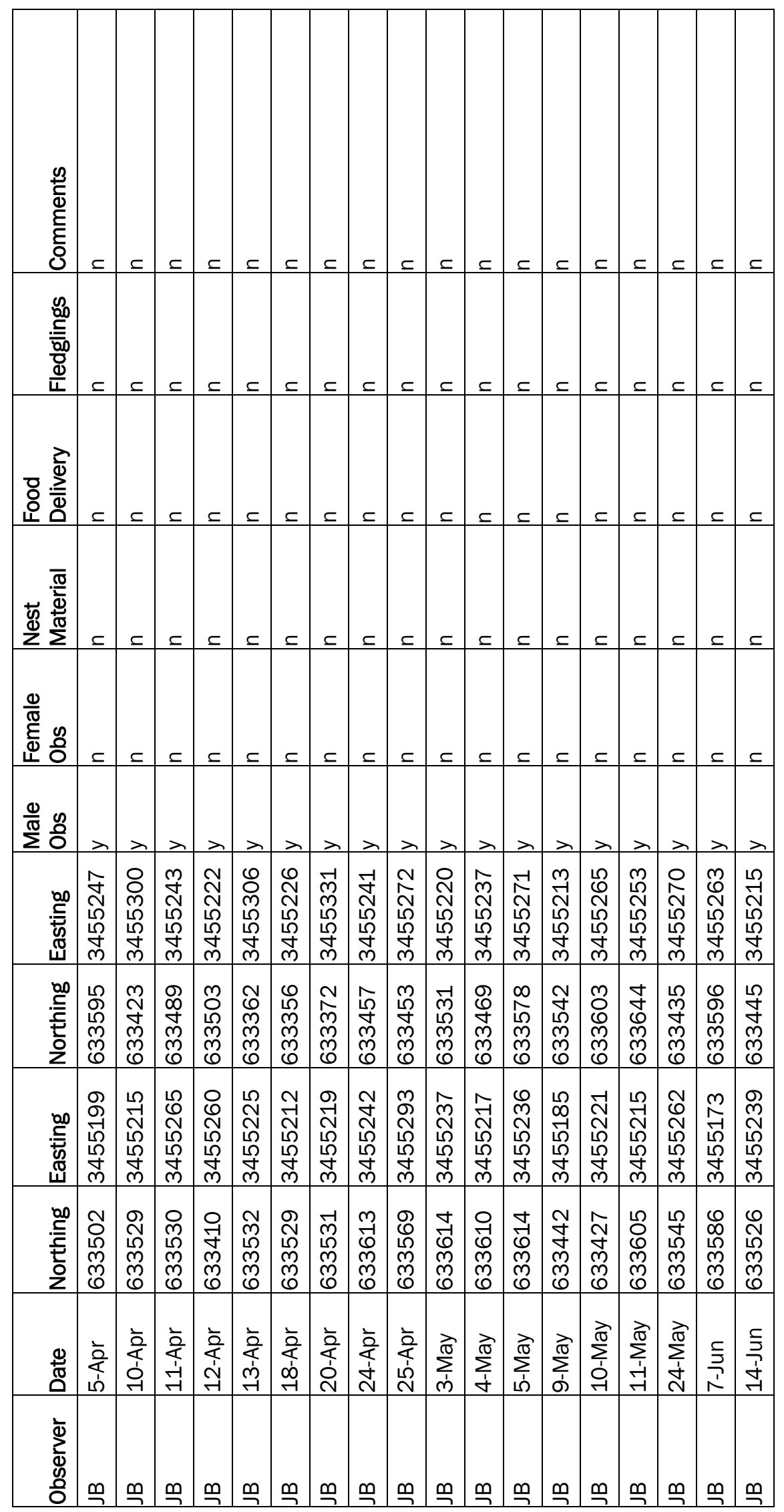




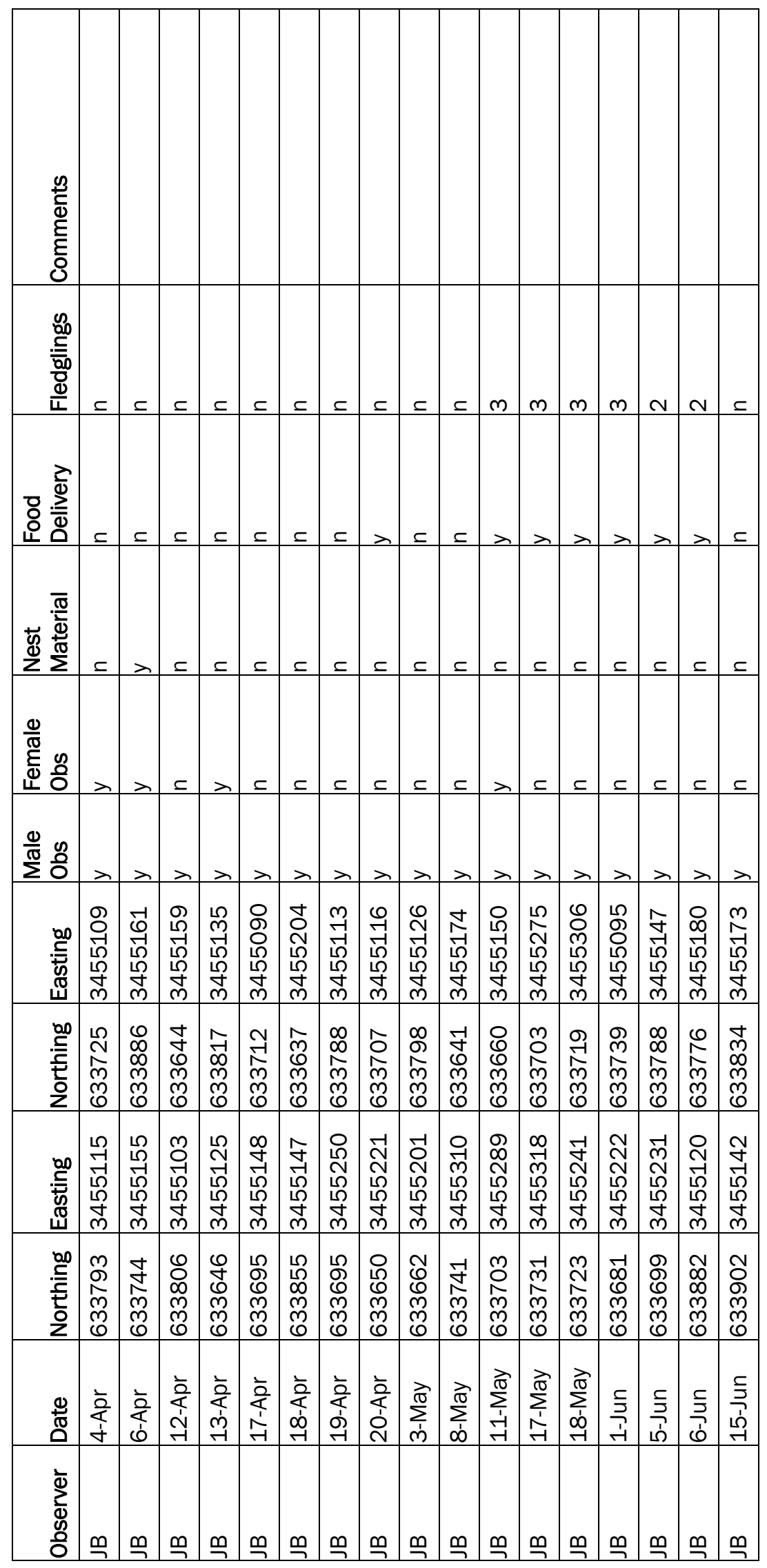



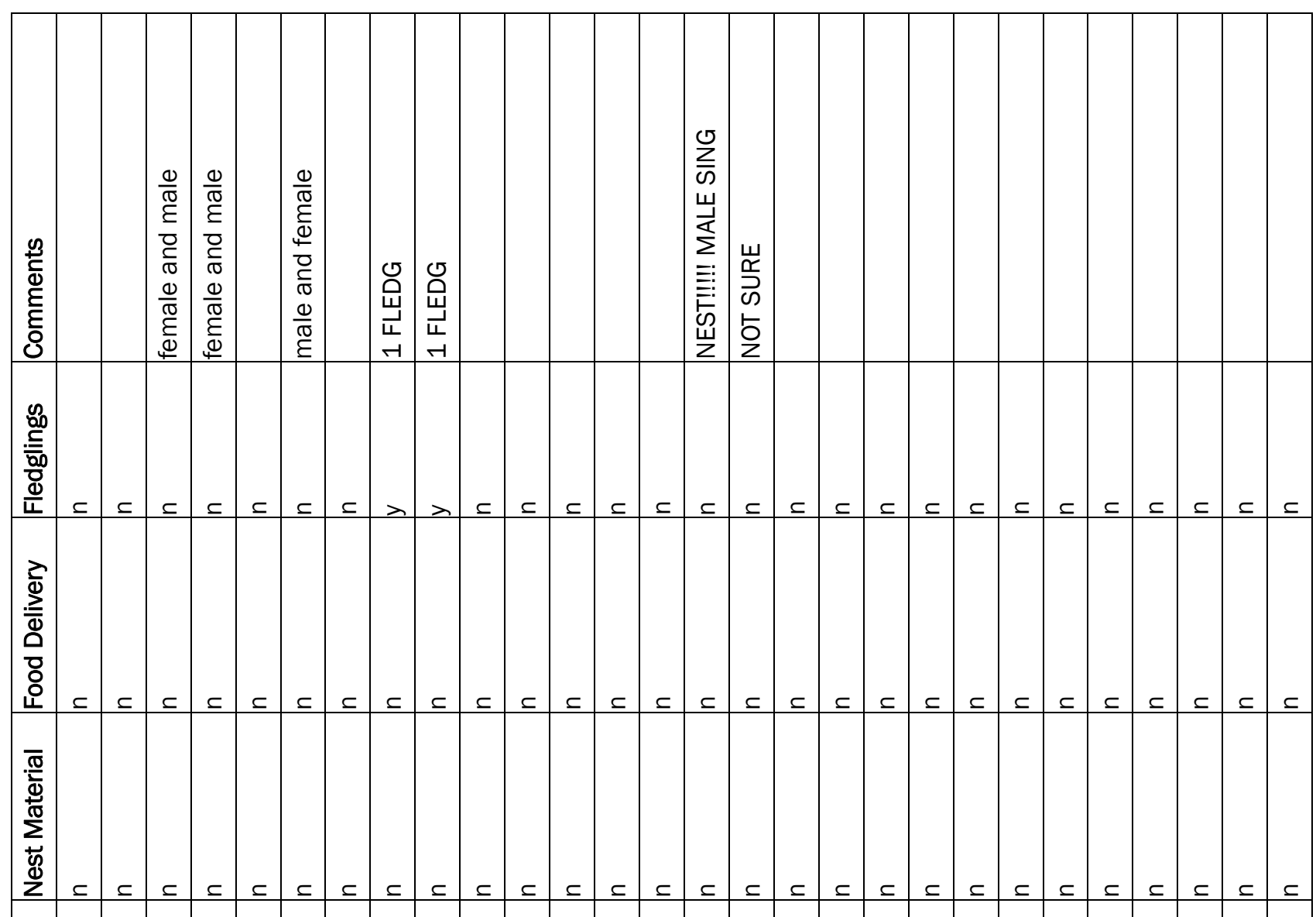

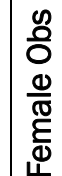

$\mathscr{0}$
0
$\frac{0}{\pi}$
$\Sigma$

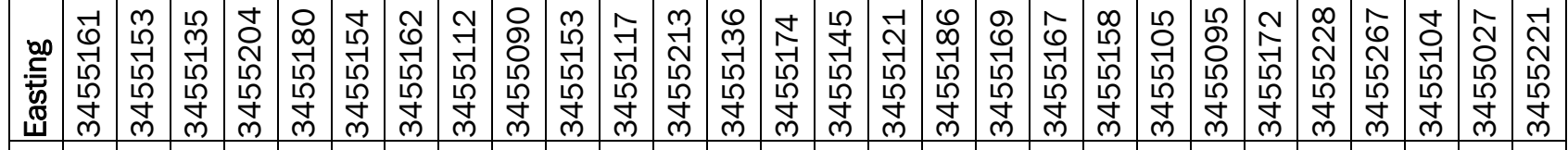

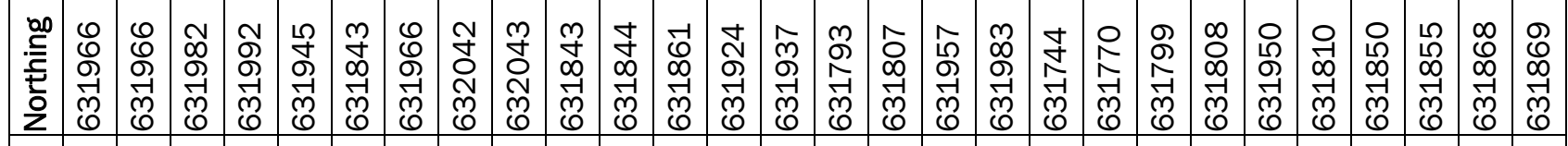

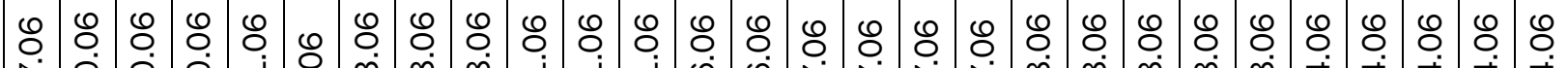

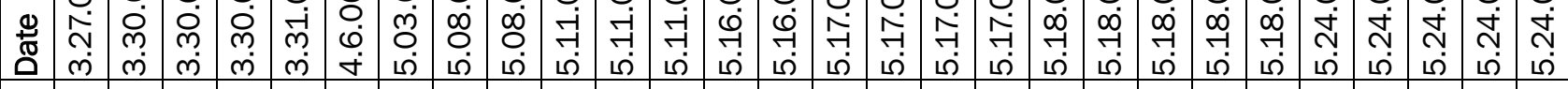

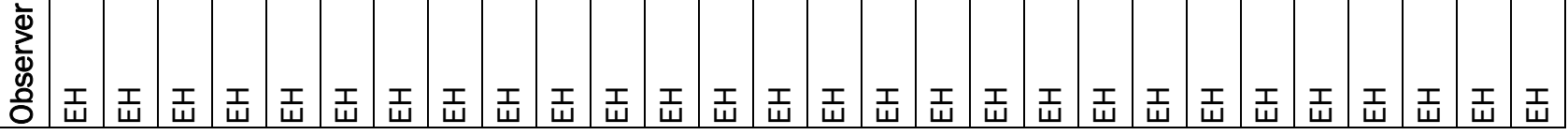




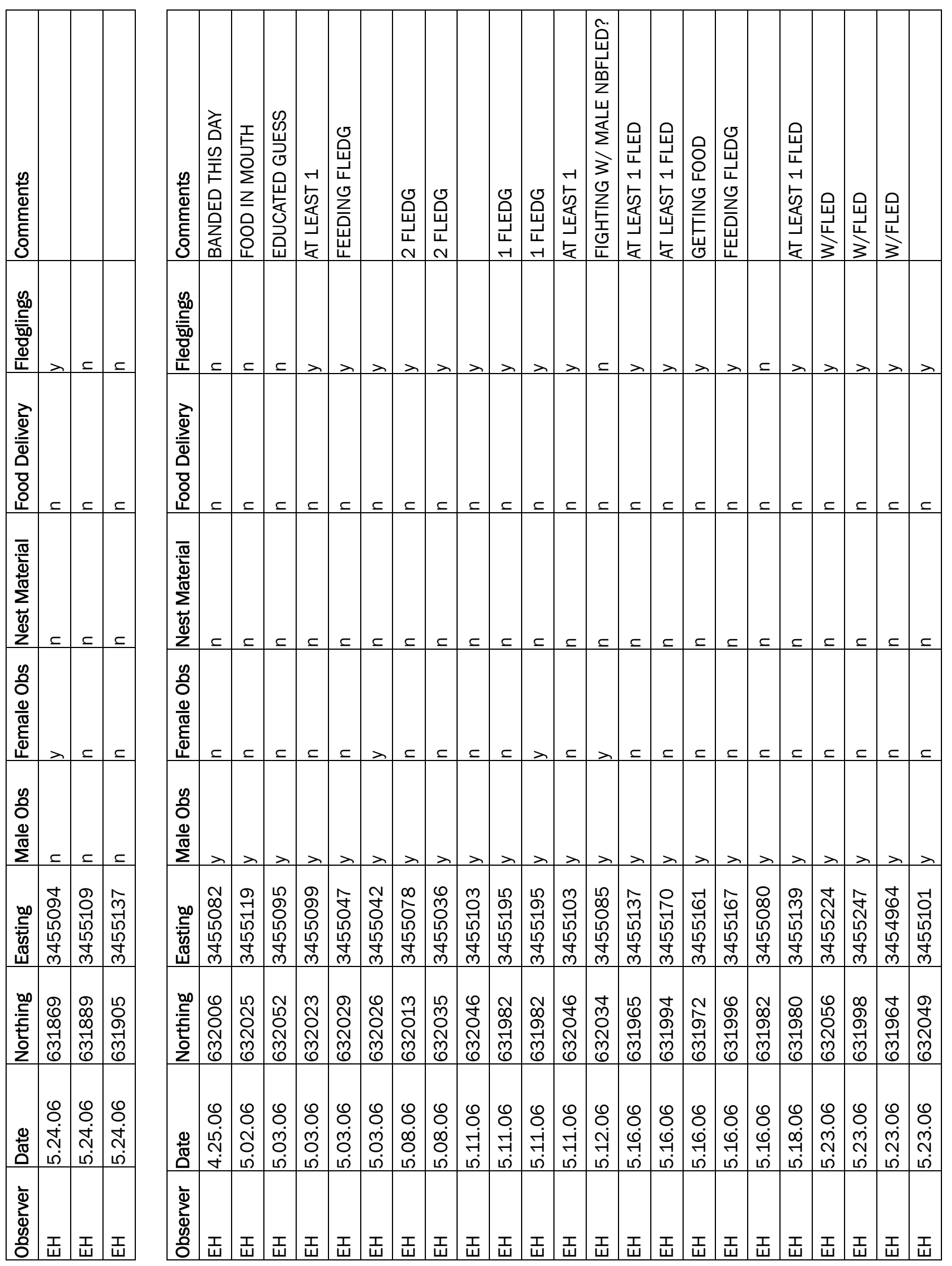



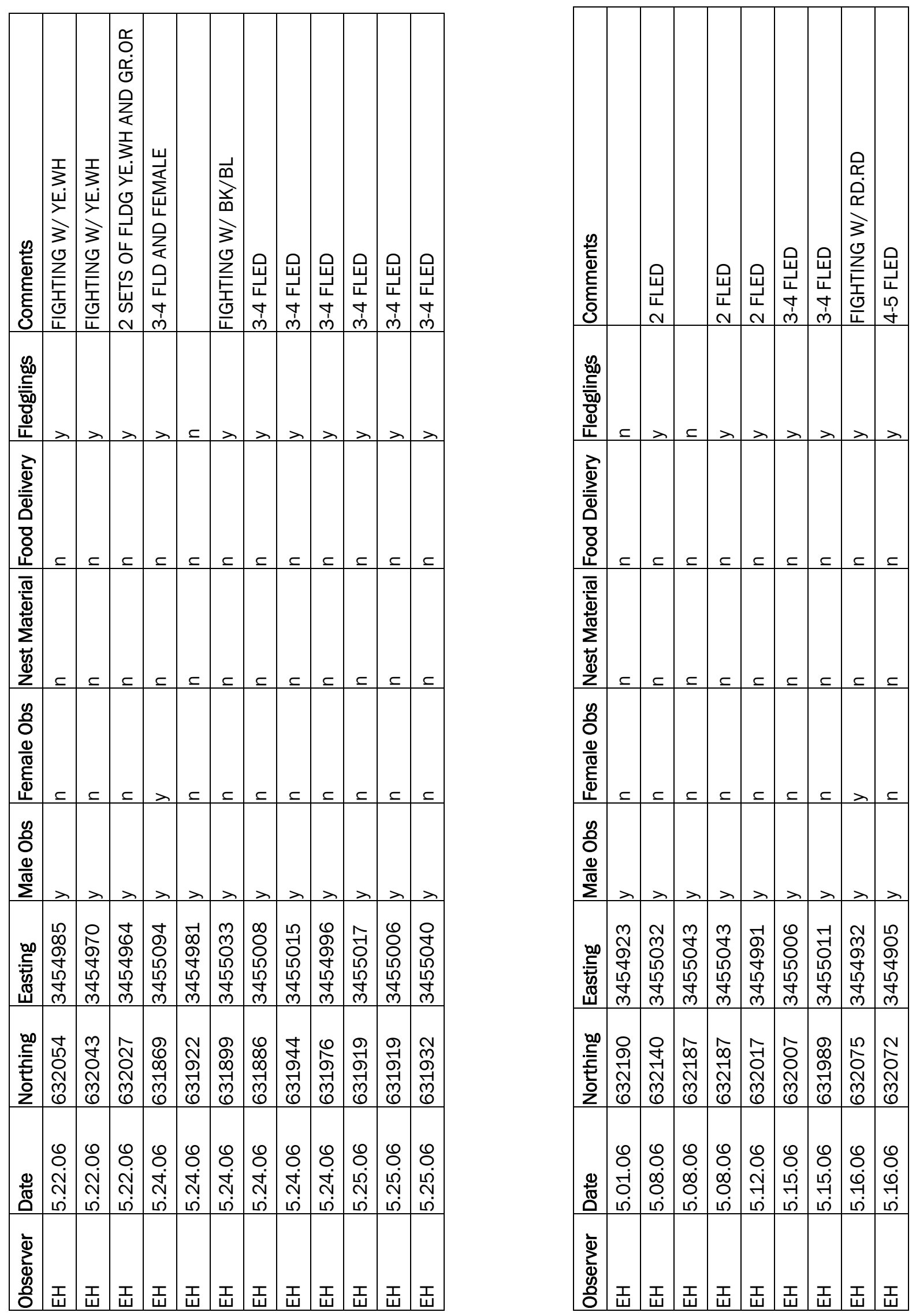


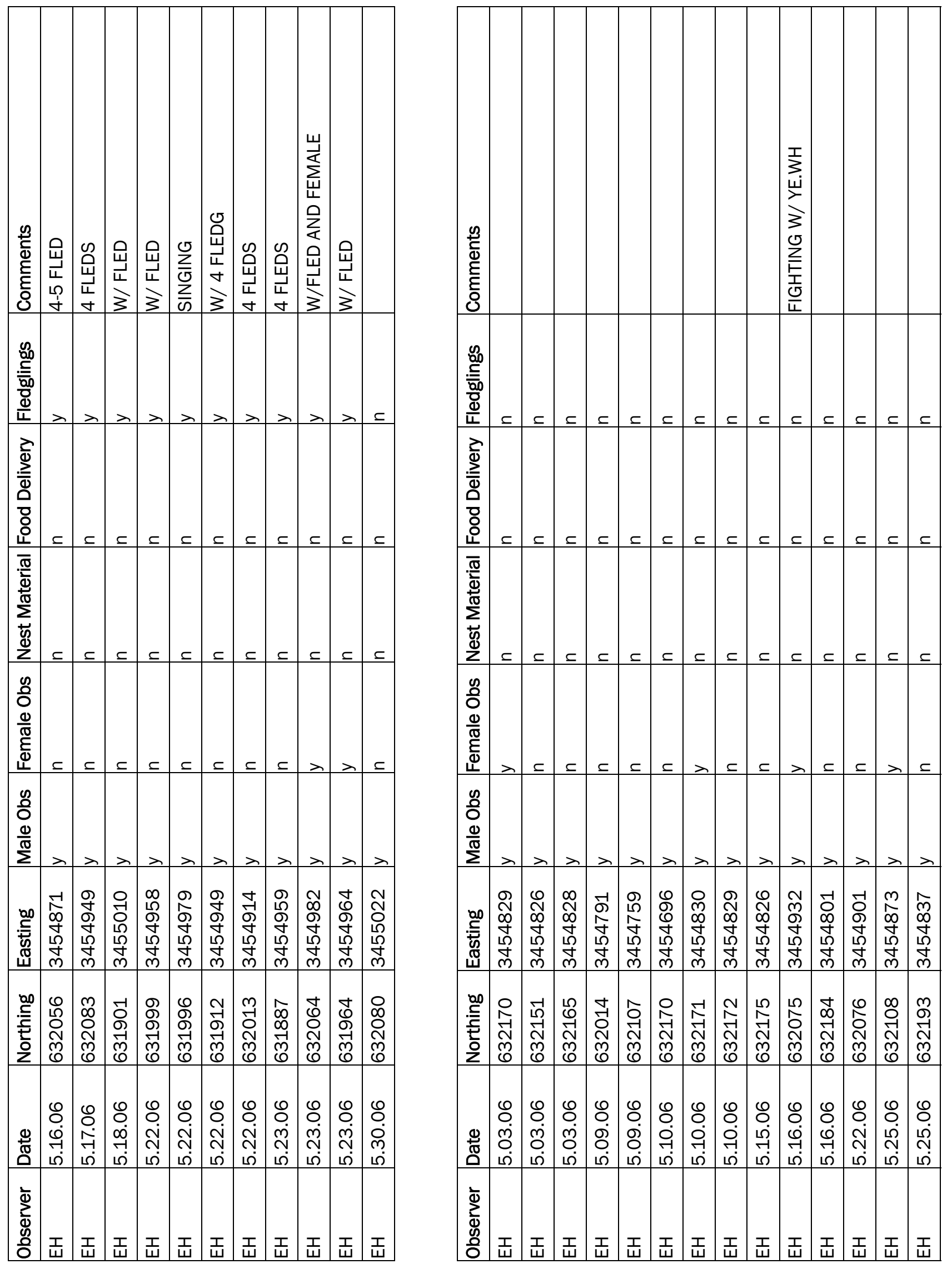



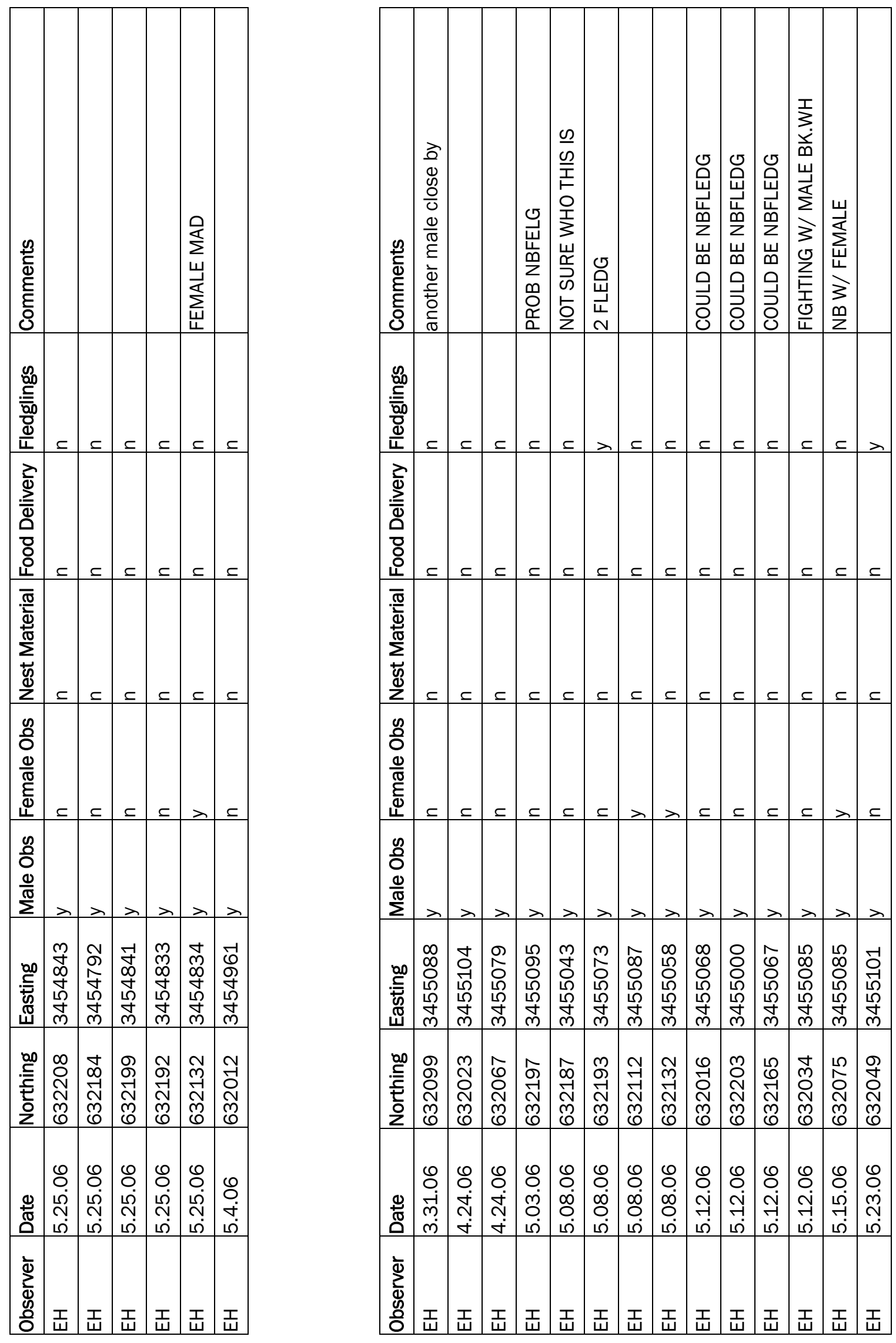

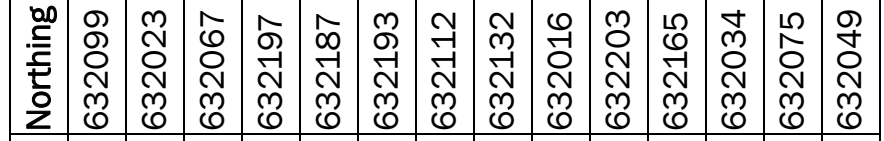

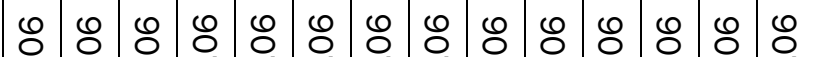

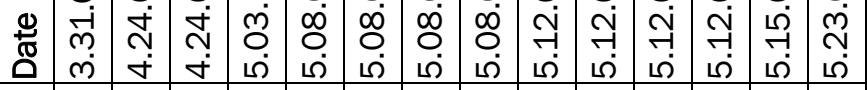

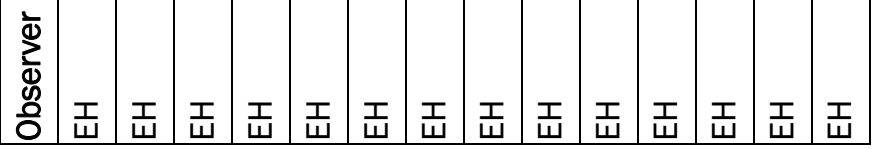




\section{Appendix C: Nest Monitoring Data}

\begin{tabular}{|l|l|l|l|}
\hline Nest 01 & & & \\
\hline OBS & DATE & TIME & COMMENTS \\
\hline MB & 10-Apr & $600-700$ & nest found N 632642 E 3456288 \\
\hline MB & 13-Apr & $600-700$ & no sign of male or female \\
\hline MB & 17-Apr & $600-700$ & female incubating \\
\hline MB & 24-Apr & $600-700$ & female bringing food to nest \\
\hline MB & 2-May & $600-700$ & male and female bringing food to nest \\
\hline MB & 4-May & $600-700$ & male and female bringing food to nest \\
\hline MB & 7-May & $600-700$ & male and female bringing food to nest 2-3 nestlings \\
\hline MB & 8-May & $600-700$ & young fledged \\
\hline
\end{tabular}

\begin{tabular}{|l|l|l|l|}
\hline NEST 02 & & & \\
\hline OBS & DATE & TIME & COMMENTS \\
\hline EH & 17-May & 1042 & found female on nest, male singing nearby \\
\hline EH & 18-May & 653 & female not on nest \\
\hline EH & 25-May & 638 & female on nest \\
\hline EH & 30-May & 705 & female on nest \\
\hline EH & 1-Jun & 1002 & female not on nest \\
\hline & & & fate of nest unknown \\
\hline
\end{tabular}




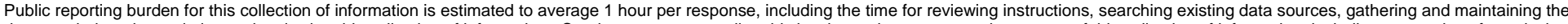

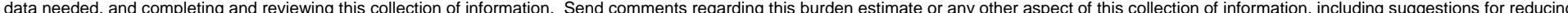

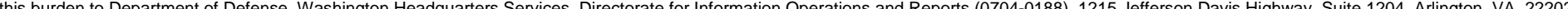

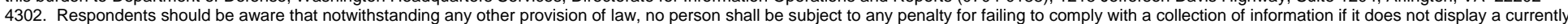
4302. Respondents should be aware that notwithstanding any other provision of law, no person shat
valid OMB control number. PLEASE DO NOT RETURN YOUR FORM TO THE ABOVE ADDRESS

\section{REPORT DATE (DD-MM-YYYY) \\ 04-2007}

4. TITLE AND SUBTITLE

Survey of the Golden-Cheeked Warbler on Fort Hood in Support of NEPA Requirements
3. DATES COVERED (From - To)

5a. CONTRACT NUMBER

5b. GRANT NUMBER

5c. PROGRAM ELEMENT NUMBER

6. AUTHOR(S)

Bruce MacAllister, Michael Baranski, Tim Hayden, and Rebecca Peak

\section{5d. PROJECT NUMBER}

5e. TASK NUMBER

5f. WORK UNIT NUMBER

8. PERFORMING ORGANIZATION REPORT NUMBER

ERDC/CERL TR-07-10

10. SPONSOR/MONITOR'S ACRONYM(S)

11. SPONSOR/MONITOR'S REPORT NUMBER(S)

\section{DISTRIBUTION I AVAILABILITY STATEMENT}

Approved for public release; distribution is unlimited.

\section{SUPPLEMENTARY NOTES}

Copies are available from the National Technical Information Service, 5285 Port Royal Road, Springfield, VA 22161.

\section{ABSTRACT}

This research on the golden-cheeked warbler (GCW) was conducted on Fort Hood, Texas, during April and June 2006. Subject matter experts on Fort Hood were consulted and helped determine which areas of the installation contained suitable GCW habitat but were not already included in The Nature Conservancy's intensive study program. Researchers then surveyed one of these areas, documenting the presence of GCW. This research was conducted to determine if data collected in the intensive study area has been successfully extrapolated to other areas of habitat on the installation.

The collected data showed that the territory density was lower than those found on TNC's intensive study areas, but pairing success was very similar to the TNC data, and the number of territorial males producing $\geq 1$ fledgling was considerably higher than TNC's estimates.

This study supports the possibility of extrapolating TNC's data to areas on Fort Hood that have not been intensively sampled. However, the small scope of this project and relatively low sample size make it necessary to preface the results with one caveat: additional years of data collection on this study site would equate to a higher measure of confidence in the results.

\section{SUBJECT TERMS}

Golden-cheeked warbler ecological surveys
Fort Hood, TX

The Nature Conservancy (TNC) bird populations

National Environmental Policy Act (NEPA)

\section{SECURITY CLASSIFICATION OF:}

\section{a. REPORT}

Unclassified

\section{b. ABSTRACT}

Unclassified

\section{LIMITATION} OF ABSTRACT

c. THIS PAGE Unclassified

\section{NUMBER} OF PAGES

SAR
50 19a. NAME OF RESPONSIBLE PERSON Bruce MacAllister

19b. TELEPHONE NUMBER (include area code) (217) 352-6511, ext 4439 